Check for updates

Cite this: RSC Adv., 2019, 9, 33472

Received 13th July 2019

Accepted 26th September 2019

DOI: 10.1039/c9ra05362j

rsc.li/rsc-advances

\section{Chemically and thermally activated persulfate for theophylline degradation and application to pharmaceutical factory effluent $\uparrow$}

\author{
Suha Al Hakim, Abbas Baalbaki, Omar Tantawi and Antoine Ghauch (D) *
}

Degradation of PPCPs by AOPs has gained major interest in the past decade. In this work, theophylline (TP) oxidation was studied in thermally (TAP) and chemically (CAP) activated persulfate systems, separately and in combination (TCAP). For [TP $]_{0}=10 \mathrm{mg} \mathrm{L}^{-1}$, (i) TAP resulted in $60 \% \mathrm{TP}$ degradation at $[\mathrm{PS}]_{0}=5 \mathrm{mM}$ and $T$ $=60^{\circ} \mathrm{C}$ after $60 \mathrm{~min}$ of reaction and (ii) CAP showed slight degradation at room temperature; however, (iii) TCAP resulted in complete TP degradation for $[\mathrm{PS}]_{0}=\left[\mathrm{Fe}^{2+}\right]_{0}=2 \mathrm{mM}$ at $T=60^{\circ} \mathrm{C}$ following a pseudo-first order reaction rate with calculated $k_{\mathrm{obs}}=5.6( \pm 0.4) \times 10^{-2} \mathrm{~min}^{-1}$. In the TCAP system, the $[\mathrm{PS}]_{0}:\left[\mathrm{Fe}^{2+}\right]_{0}$ ratio of $1: 1$ presented the best results. A positive correlation was obtained between the TP degradation rate and increasing temperature and $[\mathrm{PS}]_{0}$, and a negative correlation was obtained with increasing $\mathrm{pH}$. Both chloride and humic acid inhibited the degradation process, while nitrates enhanced it. TP dissolved in spring, sea and waste water simulating real effluents showed lower degradation rates than in DI water. Waste water caused the highest inhibition $\left(k_{\text {obs }}=2.6( \pm 0.6) \times 10^{-4} \mathrm{~min}^{-1}\right)$. Finally, the TCAP system was tested on a real factory effluent highly charged with TP, e.g. [TP] $]_{0}=160 \mathrm{mg} \mathrm{L}^{-1}$, with successful degradation under the conditions of $60^{\circ} \mathrm{C}$ and $[\mathrm{PS}]_{0}=\left[\mathrm{Fe}^{2+}\right]_{0}=50 \mathrm{mM}$.

\section{Introduction}

Theophylline (TP), or 1,3-dimethyl-7H-purine-2,6-dione, is a crystalline compound that is used in the treatment of respiratory diseases such as asthma and wheezing; it is also found in trace amounts in normal diet foods, such as tea and cocoa beans. ${ }^{1,2}$ TP belongs to the pharmaceuticals and personal care products (PPCPs) family, whose members have gained global attention in the past few decades as emerging contaminants. This increased attention is attributed to the discovery of PPCPs in ground and surface water, aided by advancements in analytical techniques which enable their detection at previously undetectable concentrations. ${ }^{3}$ The presence of PPCPs in water, even at low concentrations, poses environmental hazards and possible public health risks. Among these risks are bioaccumulation, such as the accumulation of lipophilic PPCPs in aquatic organisms ${ }^{\mathbf{4 , 5}}$ and the development of antibiotic resistance, ${ }^{6}$ in addition to uncertain synergistic/antagonist effects of long term exposure to mixtures of pharmaceuticals at low concentrations. ${ }^{7}$ TP is introduced into nature by several pathways, such as from untreated pharmaceutical production plant wastewater effluents, in addition to domestic wastewater, which

American University of Beirut, Faculty of Arts and Sciences, Department of Chemistry, P.O.Box 11-0236 Riad El Solh, 1107-2020 Beirut, Lebanon.E-mail: antoine.ghauch@ aub.edu.lb; Fax: +961 1365217; Tel: +961 1350000

$\dagger$ Electronic supplementary information (ESI) available. See DOI: $10.1039 / \mathrm{c} 9 \mathrm{ra} 05362 \mathrm{j}$ can contain TP from direct disposal of the drug and from urine excretion; this contributes to the pollution of water bodies by TP. ${ }^{8,9}$

To solve the problem of water contamination by several pollutants, water treatment plants are integrated to treat wastewater discharges from domestic, agricultural and industrial sources. Conventional water treatment methods include, but are not limited to, carbon adsorption, chemical precipitation, evaporation and ion exchange. ${ }^{10}$ It has been shown that conventional methods do not treat PPCPs efficiently; PPCPs are resistant to such treatment and have been detected in drinking water. ${ }^{\mathbf{1 1 - 1 3}}$ One of the pharmaceuticals detected in water is TP. It was found in spring water in Lebanon, possibly due to the discharge of untreated waste water. ${ }^{\mathbf{1 4}}$ TP degradation has been studied during the past decades by several methods, including degradation by means of ferrate $(\mathrm{vI})^{15}$ and a metal organic framework (Pd@MIL-100(Fe)) with visible light $(\lambda \geq 420 \mathrm{~nm}),{ }^{16}$ $\mathrm{UV} / \mathrm{H}_{2} \mathrm{O}_{2},{ }^{17,18}$ and $\mathrm{UV} / \mathrm{TiO}_{2}$ nanobelts. ${ }^{19}$ Novel water treatment methods include advanced oxidation processes (AOPs), which have been proved to be significantly efficient in removing persistent organic compounds. A wide variety of techniques involving different oxidants and different methods of activation are used in AOPs; examples include Fenton, ${ }^{20}$ photo-Fenton, ${ }^{21}$ $\mathrm{UV} / \mathrm{PS},{ }^{22,23} \mathrm{Fe} / \mathrm{PS},{ }^{24,25}$ and heat/PS ${ }^{26-29}$ systems, in addition to alkaline/PS and alkaline/peroxymonosulfate ${ }^{30}$ systems. PS and $\mathrm{H}_{2} \mathrm{O}_{2}$ are the two most commonly used effective oxidants in AOPs; however, PS poses some advantages over $\mathrm{H}_{2} \mathrm{O}_{2}$ in terms of cost, safety in handling, and ease of access in some regions. PS 
is effective in degrading several pharmaceuticals; ${ }^{31-34}$ however, to our knowledge, it has not been tested by other research groups to treat TP. The main PS activation methods are UV, chemical, and heat activation, which generate highly reactive sulfate radicals (SRs) (eqn (1)-(3))..$^{2-29,34,35}$ Our research group has recently studied TP degradation by UV-activated PS. ${ }^{36}$

In this study, TP degradation by thermally activated PS (TAP) and chemically activated PS (CAP) was studied separately as well as in a combined thermally and chemically activated PS (TCAP) system. The combination of activation techniques was applied, for the first time, to simulated effluents and to a real highly concentrated pharmaceutical effluent collected from a local pharmaceutical factory. The degradation process was optimized by testing several parameters in order to obtain efficient degradation within a reasonable time at an affordable cost. Finally, charge distribution and frontier orbital calculations were investigated in order to better elucidate the TP degradation mechanism by oxidative radical species in solution.

$$
\begin{gathered}
\mathrm{S}_{2} \mathrm{O}_{8}{ }^{2-} \rightarrow 2 \mathrm{SO}_{4}{ }^{--} \text {(thermal activation) } 30{ }^{\circ} \mathrm{C}<T<99{ }^{\circ} \mathrm{C} \\
\mathrm{S}_{2} \mathrm{O}_{8}{ }^{2-}+\mathrm{Fe}^{2+} \rightarrow \mathrm{SO}_{4}{ }^{2-}+\mathrm{SO}_{4}{ }^{--}+\mathrm{Fe}^{3+} \text { (chemical activation)(2) } \\
\mathrm{S}_{2} \mathrm{O}_{8}{ }^{2-}+h \nu \rightarrow 2 \mathrm{SO}_{4}{ }^{--} \text {(UV activation) }
\end{gathered}
$$

\section{Materials and methods}

\subsection{Chemicals}

Theophylline $\left(\mathrm{C}_{7} \mathrm{H}_{8} \mathrm{~N}_{4} \mathrm{O}_{2}\right)\left(\mathrm{C}_{7} \mathrm{H}_{8} \mathrm{~N}_{4} \mathrm{O}_{2}, \geq 99 \%\right)$ and sodium persulfate (PS) $\left(\mathrm{Na}_{2} \mathrm{~S}_{2} \mathrm{O}_{8}, \geq 99.0 \%\right)$, were obtained from SigmaAldrich (China and France, respectively). Methanol ( $\mathrm{MeOH}$, $\mathrm{CH}_{4} \mathrm{O}$ ) and tertiary butyl alcohol (TBA) of HPLC grade were purchased from Sigma-Aldrich (Germany). $\mathrm{MeOH}$ was used as the mobile phase for chromatographic analysis in combination with deionized water (DI). Ferrous chloride tetrahydrate $\left(\mathrm{FeCl}_{2} \cdot 4 \mathrm{H}_{2} \mathrm{O}\right)$, used as a chemical activator for PS, was obtained from Fluka (Switzerland). $\mathrm{HCl}$ (37\%) was obtained from Fluka (Netherlands) and used to dissolve $\mathrm{FeCl}_{2}$ in the preparation of stock solutions. To evaluate the effects of ionic additives, sodium chloride $(\mathrm{NaCl})$ was purchased from Fluka (Netherlands), and sodium nitrate $\left(\mathrm{NaNO}_{3}\right)$ was obtained from SigmaAldrich (Germany). DI water was used for the preparation of all solutions in this study.

\subsection{Chemical analysis: TP quantification and identification}

High performance liquid chromatography (HPLC, Agilent 1100 series) was used for TP quantification. The HPLC was equipped with a thermo-electrically cooled autosampler unit, a quaternary pump, a vacuum degasser, and a thermally controlled column. Separation of TP from other by-products was enabled by the use of a C-18 reverse phase column (Discovery ${ }^{\circledR} \mathrm{HS}, 5 \mu \mathrm{m}$; $4.6 \mathrm{~mm}$ internal diameter $\times 250 \mathrm{~mm}$ length) connected to a guard column (HS C-18, $5 \mu \mathrm{m} ; 4.0 \mathrm{~mm}$ internal diameter, $20 \mathrm{~mm}$ length) (Pennsylvania, USA). The temperature of the column was set at $30{ }^{\circ} \mathrm{C}$, while that of the autosampler compartment was set at $4{ }^{\circ} \mathrm{C}$. A column flow rate of 0.5 $\mathrm{mL} \min ^{-1}$ was used with a mobile phase consisting of water and $\mathrm{MeOH}$ (70 : 30 ratio) maintained in isocratic mode. The injection volume was set at $80 \mu \mathrm{L}$. A diode-array detector for the quantification of TP was coupled to the HPLC. For the aforementioned conditions, the TP retention time was observed to be 12 min. All samples were filtered using $0.45 \mu \mathrm{m}$ PTFE $13 \mathrm{~mm}$ disc filters (Jaytee Biosciences Ltd., UK) before HPLC analysis. Selected TP chemical properties in addition to the calibration curve and the corresponding LINEST output are summarized in ESI Fig. 1S(a-c).† Identification of the degradation and transformation products of TP was performed on an Ultimate 3000 RSLC Thermo Scientific HPLC-MS/MS connected to a Q Exactive Orbitrap. A Hypersil GOLD C18 150 column $(100 \times 2.1 \mathrm{~mm}, 1.9$ $\mu \mathrm{m})$ was used for separation. The injection volume was set as 2 $\mu \mathrm{L}$ and the elution process was performed at a flow rate of 0.3 $\mathrm{mL} \min ^{-1}$ using DI water (containing $0.1 \%$ formic acid) as eluent $\mathrm{A}$ and methanol as eluent $\mathrm{B}$. The mass spectrometer was operated in positive ionization mode. The auxiliary gas heater temperature was set as $350{ }^{\circ} \mathrm{C}$ and the capillary temperature was $320{ }^{\circ} \mathrm{C}$.

\subsection{Experimental setup}

The experimental setup consisted of $200 \mathrm{~mL}$ Erlenmeyer flasks used as reactors and immersed in a controlled-temperature water bath. The latter was equipped with an orbital shaker (Wise Bath WSB-30) and amended with a homemade Plexiglas cover plate with the capacity to hold all the Erlenmeyer flasks by their necks in order to prevent the reactors from falling (Fig. $2 \mathrm{~S} \dagger$ ). The experimental setup could accommodate up to 12 reactors at a time, and all experiments were performed in triplicate. The reactors were efficiently submerged in the water bath to ensure that their temperatures matched that of the surrounding water. This was further guaranteed by the measurement of the inner temperature of the reactor using a thermometer. The temperatures tested were room temperature in addition to $40{ }^{\circ} \mathrm{C}$ to $75{ }^{\circ} \mathrm{C}$. To ensure proper homogenization and heat distribution, the orbital shaker was set at 70 revolutions per minute throughout the experiments.

\subsection{Experimental procedure}

The stock solutions were prepared as follows: TP $\left(100 \mathrm{mg} \mathrm{L}^{-1}\right)$ was prepared by dissolving $100 \mathrm{mg}$ of dry TP powder in $1 \mathrm{~L}$ of DI water; PS (100 mM) was prepared by dissolving $2.38 \mathrm{~g}$ of sodium persulfate in $100 \mathrm{~mL}$ of $\mathrm{DI} ; \mathrm{FeCl}_{2}(80 \mathrm{mM})$ was prepared by dissolving $3.1808 \mathrm{~g}$ of $\mathrm{FeCl}_{2} \cdot 4 \mathrm{H}_{2} \mathrm{O}$ in concentrated $\mathrm{HCl}(37 \%)$ in a $250 \mathrm{~mL}$ volumetric flask, followed by the addition of DI. The stock solutions were prepared weekly and stored in the dark at $4{ }^{\circ} \mathrm{C}$. The water bath was turned on before the experiments to attain the required temperature. The reactors outside the water bath were each filled with predetermined amounts of prepared concentrated stock solutions of TP and matrix solution when required, in addition to DI water. Each obtained solution was mixed and preheated in the water bath to reach the desired temperature. Finally, the experiment was initiated by adding $\mathrm{FeCl}_{2}(20 \mathrm{mM})$ and PS (100 mM) stock solutions, reaching a final 
reactor volume of $200 \mathrm{~mL}$. Samples were withdrawn using a clean $1 \mathrm{~mL}$ syringe from every reactor, then filtered using a $0.45 \mu \mathrm{m}$ PTFE $13 \mathrm{~mm}$ disc filter and stored in $2 \mathrm{~mL}$ HPLC vials. To quench any further oxidation reactions after sample withdrawal, vials were placed in an ice bath to prevent further thermal activation of $\mathrm{PS}^{26}$ and spiked with $0.5 \mathrm{~mL}$ of methanol to prevent further chemical activation of PS. ${ }^{34}$ Waste water used in real water sample experiments was pre-filtered using a $1 \mu \mathrm{m}$ ashless glass fiber filter.

\subsection{Calculation of charge distributions and frontier orbitals}

The theoretical calculations were performed using the Gaussian 09 program $^{37}$ with density functional theory. The Becke 3parameter Lee-Yang-Parr (B3LYP $)^{38,39}$ functional was used with the $6-311++(2 d, 2 p)$ basis set. First, the molecular parameters of theophylline molecule were optimized using the mentioned level of theory. Second, at the same level of theory, the frontier electron densities and Mulliken charge distributions were obtained utilizing the optimized parameters.

\section{Results and discussion}

\subsection{Thermal activation of PS (TAP system)}

3.1.1. Thermal stability of TP and effects of $[\mathrm{PS}]_{0}$. To test the stability and behaviour of TP molecules under thermal stress, control experiments were conducted in a PS-free medium with $[\mathrm{TP}]_{0}=10 \mathrm{mg} \mathrm{L}^{-1}$ at different temperatures $\left(40-75^{\circ} \mathrm{C}\right)$ for a total reaction time of $60 \mathrm{~min}$.

As can be noted in Fig. 3S, $\uparrow$ heat did not significantly affect the stability of TP in aqueous solutions. In fact, a slight decline in the concentration of TP was observed, with a maximum of about $5 \%$ for $T=40-75{ }^{\circ} \mathrm{C}$, demonstrating the thermal stability of TP.
Thermal activation was tested by spiking a $[\mathrm{TP}]_{0}=10 \mathrm{mg} \mathrm{L}^{-1}$ solution with different concentrations of PS at $60{ }^{\circ} \mathrm{C}$. Table 1 and Fig. $4 \mathrm{~S} \dagger$ show that the TP degradation increased from $3 \%$ to $60 \%$ with increasing $[\mathrm{PS}]_{0}$ from $0.25 \mathrm{mM}$ to $5 \mathrm{mM}$, respectively, after a period of $60 \mathrm{~min}$. This increase in the \% degradation is attributed to the production of more $\mathrm{SO}_{4}{ }^{-}$in the more PSconcentrated solution, as per eqn (1).

3.1.2. Effects of temperature and determination of activation energy. The effects of temperature on TP degradation by the TAP system were studied under the following conditions: $[\mathrm{TP}]_{0}=10 \mathrm{mg} \mathrm{L}^{-1},[\mathrm{PS}]_{0}=2 \mathrm{mM}$ and $T=55-75^{\circ} \mathrm{C}$. Fig. 1a shows that increasing the temperature resulted in improved TP degradation. For example, when temperature increased from $55{ }^{\circ} \mathrm{C}$ to $75{ }^{\circ} \mathrm{C}$, the $\%$ TP degradation increased from $10 \%$ to $100 \%$ at $t=40 \mathrm{~min}$. This observed trend has been found in several studies of TAP systems. ${ }^{26,28}$ This can be explained by the increase in the energy provided to the system upon heating, which in its turn favors increasing numbers of collisions between the reacting TP and SRs.

The observed degradation rate constant $\left(k_{\mathrm{obs}}\right)$ was calculated according to the pseudo-first order kinetics model using eqn (4), which showed good fit (Text S2 $\dagger$ ). Additionally, the activation energy $\left(E_{\mathrm{A}}\right)$ of the TP degradation reaction in the TAP system was determined using the Arrhenius equation (eqn (5)), where $T$ is the temperature in $\mathrm{K}, k_{\mathrm{obs}}$ is the observed degradation rate constant calculated at different temperatures in $\min ^{-1}, A$ is the Arrhenius constant, and $R$ is the gas constant $\left(8.314 \mathrm{~J} \mathrm{~mol}^{-1}\right.$ $\mathrm{K}^{-1}$ ). eqn (5) was plotted, and the slope obtained represents $\frac{E_{\mathrm{A}}}{R}$ (Fig. 1b). $E_{\mathrm{A}}$ and $\ln (A)$ were determined to be $154( \pm 16) \mathrm{kJ} \mathrm{mol}^{-1}$ and $50( \pm 5) \mathrm{kJ} \mathrm{mol}^{-1}$, respectively. The $E_{\mathrm{A}}$ value is close to those reported by Ghauch et al. for ibuprofen, $E_{\mathrm{A}}=168( \pm 9) \mathrm{kJ} \mathrm{mol}^{-1}$, and naproxen, $E_{\mathrm{A}}=155.03( \pm 26.4) \mathrm{kJ} \mathrm{mol}^{-1}$, both using a TAP

Table $1 \%$ TP degradation in the TAP system at $T=55-75{ }^{\circ} \mathrm{C}$ and different $[P S]_{0}$, and in the CAP system at room temperature. Experimental conditions: $[\mathrm{PS}]_{0}=0.25-5 \mathrm{mM},[\mathrm{PS}]_{0}:\left[\mathrm{Fe}^{2+}\right]_{0}$ ratios $=1: 10,1: 5$ and $1: 1$, and $[\mathrm{TP}]_{0}=10 \mathrm{mg} \mathrm{L}^{-1}$ for all studied cases

\begin{tabular}{|c|c|c|c|c|c|c|}
\hline \multirow[t]{5}{*}{$\mathrm{TA}^{a}$} & 10 & 55 & 2 & - & 14 & $3.83 / 3.69$ \\
\hline & & & 1 & & 12 & $3.87 / 3.75$ \\
\hline & & & 2 & & 28 & $3.83 / 3.58$ \\
\hline & & & 5 & & 60 & $3.41 / 3.05$ \\
\hline & & 75 & & & 100 & $3.50 / 3.22$ \\
\hline \multirow[t]{5}{*}{$\mathrm{CA}^{b}$} & 10 & 20 & 0.25 & 0.025 & 0.5 & $3.48 / 3.83$ \\
\hline & & & & 0.125 & - & $2.97 / 2.84$ \\
\hline & & & & 0.25 & 5 & $2.81 / 2.54$ \\
\hline & & & 1 & 0.1 & 4 & $2.96 / 3.18$ \\
\hline & & & & 0.05 & - & $2.43 / 2.30$ \\
\hline
\end{tabular}

${ }^{a}$ Check Fig. 4S, Fig. 1a. ${ }^{b}$ Check Fig. 5S 
system; however, they used half the $[\mathrm{PS}]_{0}$ used in this work, e.g. $1 \mathrm{mM}^{26,28}$ The uncertainties reported for $\ln (A)$ and $E_{\mathrm{A}}$ were determined using the LINEST function of Microsoft Excel.

$$
\begin{gathered}
\ln \frac{[\mathrm{TP}]}{[\mathrm{TP}]_{0}}=-k_{\text {obs }} t \\
\ln \left(k_{\text {obs }}\right)=\ln (A)-\frac{E_{\mathrm{A}}}{R T}
\end{gathered}
$$

\subsection{Chemical activation of PS (CAP system)}

To test the effectiveness of CAP for TP degradation at room temperature, a solution of $[\mathrm{TP}]_{0}=10 \mathrm{mg} \mathrm{L}^{-1}$ was subjected to $[\mathrm{PS}]_{0}=0.25,1$ and $5 \mathrm{mM}$ activated by $\mathrm{Fe}^{2+}$ with $[\mathrm{PS}]_{0}:\left[\mathrm{Fe}^{2+}\right]_{0}$ ratios of $10: 1,2: 1$ and $1: 1$ at favorable acidic $\mathrm{pH}$ to ensure $\mathrm{Fe}^{2+}$ solubility. Under all conditions tested, only negligible degradation of TP was observed (Fig. 5S $\dagger$ ), with a maximum of
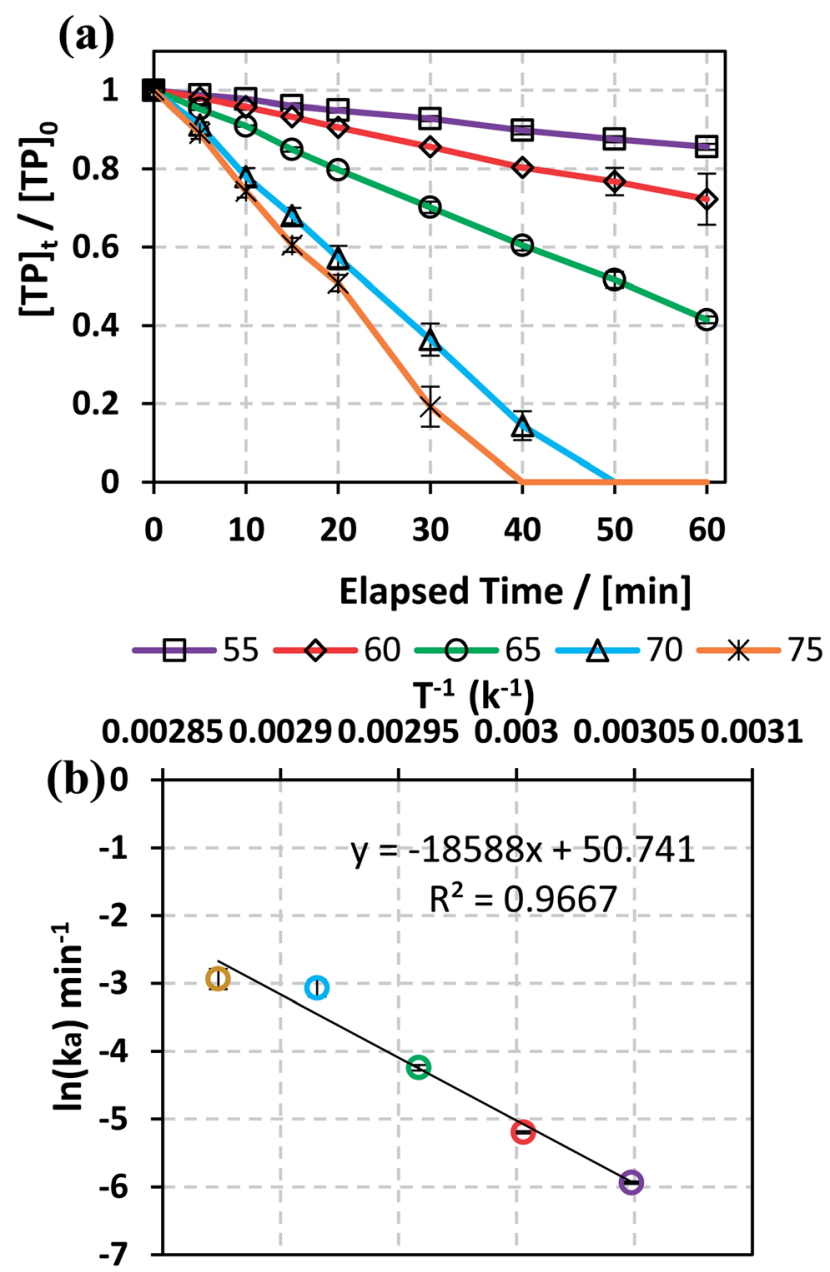

Fig. 1 (a) Effects of temperature on TP degradation in a TAP system. (b) The corresponding Arrhenius plot of $\ln \left(k_{\mathrm{a}}\right)$ vs. $(1 / T)$, showing the equation for linear best fit. Experimental conditions: $[T P]_{0}=10 \mathrm{mg} \mathrm{L}^{-1}$, $[P S]_{0}=2 \mathrm{mM}$ and $T=55-75^{\circ} \mathrm{C}$. Error bars are calculated as $\frac{t s}{\sqrt{n}}$, where absent bars fall within the symbols.
$5 \%$ TP degradation noted at $60 \mathrm{~min}$ for the case of $[\mathrm{PS}]_{0}=$ $0.25 \mathrm{mM}$ and a $[\mathrm{PS}]_{0}:\left[\mathrm{Fe}^{2+}\right]_{0}$ ratio of $1: 1$, as summarized in Table 1 . Thus, TP is demonstrated to be relatively resistant to the CAP system at room temperature compared to other organic contaminants. For example, Oh et al. obtained incomplete degradation of polyvinyl alcohol utilizing $\mathrm{Fe}^{2+}$-based CAP at room temperature and used a higher reaction temperature to secure significant degradation of the contaminant. ${ }^{40}$ This can be explained by the common scavenging effect of $\mathrm{SO}_{4}{ }^{--}$by $\mathrm{Fe}^{2+}$ to form the less effective $\mathrm{Fe}^{3+}$ ion (eqn (6)) $)^{24,41}$ in addition to the recalcitrant character of the TP molecule.

$$
\mathrm{SO}_{4}{ }^{--}+\mathrm{Fe}^{2+} \rightarrow \mathrm{SO}_{4}^{2-}+\mathrm{Fe}^{3+}
$$

\subsection{Combined thermal and chemical activation of PS (TCAP system)}

Because both TAP and CAP systems showed low to negligible performance in degrading TP in aqueous solutions, both activation methods were combined into a thermally and chemically activated PS (TCAP) system. This system was tested for different $[\mathrm{PS}]_{0}:\left[\mathrm{Fe}^{2+}\right]_{0}$ ratios, $[\mathrm{PS}]_{0}$ values and temperatures in order to positively or negatively confirm any synergistic effect that can be obtained upon combination of both PS activation techniques.

3.3.1. Effects of $[\mathrm{PS}]_{0}:\left[\mathrm{Fe}^{2+}\right]_{0}$ ratio and $[\mathrm{PS}]_{0}$. TP degradation was studied at different $[\mathrm{PS}]_{0}:\left[\mathrm{Fe}^{2+}\right]_{0}$ ratios and $[\mathrm{PS}]_{0}$ values. $[\mathrm{PS}]_{0}:\left[\mathrm{Fe}^{2+}\right]_{0}$ ratios of $10: 1,2: 1$ and $1: 1$ were tested at $[\mathrm{PS}]_{0}=0.25,1$ and $5 \mathrm{mM},[\mathrm{TP}]_{0}=10 \mathrm{mg} \mathrm{L}^{-1}$ and $T=60{ }^{\circ} \mathrm{C} . k_{\mathrm{obs}}$ was calculated for the pseudo-first order kinetics model according to eqn (4), as demonstrated in previous work (Text $\mathrm{S} 3, \uparrow$ Table 3$)$. In fact, the reaction at the early stage can be considered to be zero order in the first five minutes; ${ }^{25}$ however, as the reaction proceeds, degradation by-products form and the reaction follows pseudo-first order kinetics. As depicted in Fig. 2 and Table 2, the $1: 1[\mathrm{PS}]_{0}:\left[\mathrm{Fe}^{2+}\right]_{0}$ ratio showed the highest degradation rate in the three tested $[\mathrm{PS}]_{0}$ conditions, followed by the $2: 1$ and $10: 1$ ratios.

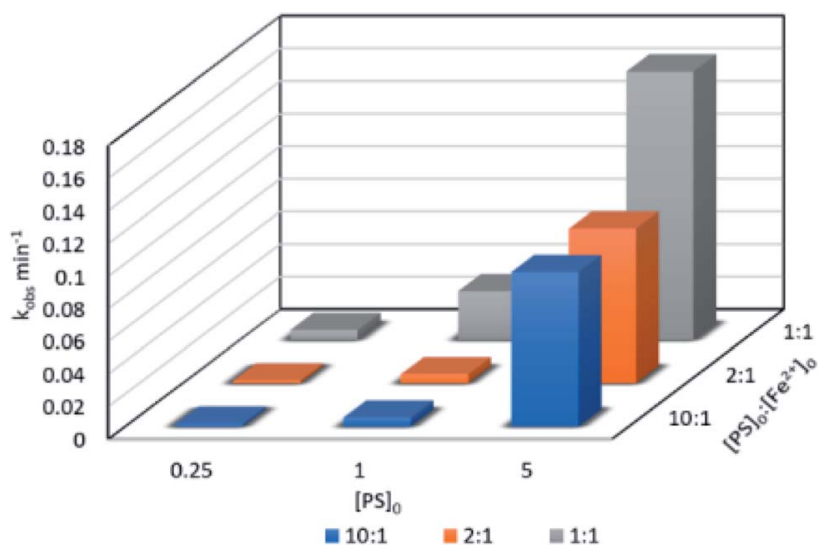

Fig. 2 Effects of the $[\mathrm{PS}]_{0}:\left[\mathrm{Fe}^{2+}\right]_{0}$ ratio on TP degradation in a TCAP system. Experimental conditions: $[\mathrm{PS}]_{0}=0.25,1$ and $5 \mathrm{mM},[\mathrm{PS}]_{0^{-}}$ $:\left[\mathrm{Fe}^{2+}\right]_{0}$ ratios of $1: 1,2: 1$ and $10: 1$, and $T=60^{\circ} \mathrm{C}$. 
Table 2 Effects of the $[\mathrm{PS}]_{0}:\left[\mathrm{Fe}^{2+}\right]_{0}$ ratio on TP degradation in a TCAP system. Initial and final $\mathrm{pH}$ values are presented for every case. Experimental conditions: $[\mathrm{PS}]_{0}=0.25,1$ and $5 \mathrm{mM},[\mathrm{PS}]_{0}:\left[\mathrm{Fe}^{2+}\right]_{0}$ ratios of $1: 1,2: 1$ and $10: 1$, and $T=60^{\circ} \mathrm{C}$

\begin{tabular}{llll}
\hline$[\mathrm{PS}]_{0}:\left[\mathrm{Fe}^{2+}\right]_{0}$ & {$[\mathrm{PS}]_{0} \mathrm{mM}$} & {$\left[\mathrm{Fe}^{2+}\right]_{0} \mathrm{mM}$} & $\mathrm{pH}_{\mathrm{i}} / \mathrm{pH}_{\mathrm{f}}$ \\
\hline $10: 1$ & 0.25 & 0.025 & $3.50 / 3.30$ \\
& 1 & 0.1 & $2.79 / 2.7$ \\
$2: 1$ & 5 & 0.5 & $2.19 / 2.07$ \\
& 0.25 & 0.125 & $2.97 / 2.85$ \\
& 1 & 0.5 & $2.53 / 2.9$ \\
$1: 1$ & 5 & 0.25 & $1.84 / 1.79$ \\
& 0.25 & 0.25 & $2.81 / 2.54$ \\
& 1 & 1 & $2.23 / 2.12$ \\
& 5 & 5 & $1.63 / 1.54$
\end{tabular}

Different studies have showed the effectiveness of different $[\mathrm{PS}]_{0}:\left[\mathrm{Fe}^{2+}\right]_{0}$ ratios. The optimum ratio obtained varies depending on different parameters, such as the target analyte, the method of iron addition, and the state/morphology of the added iron. ${ }^{42}$ For example, a study by $\mathrm{Oh}$ et al. showed that $1: 1$ $[\mathrm{PS}]_{0}:\left[\mathrm{Fe}^{2+}\right]_{0}$ was the optimum ratio for the degradation of polyvinyl alcohol by CAP. ${ }^{40}$ Also, Naim and Ghauch (2016) showed that $1: 1[\mathrm{PS}]_{0}:\left[\mathrm{Fe}^{2+}\right]_{0}$ was the most effective ratio to yield full ranitidine degradation in almost $10 \mathrm{~min} .^{24}$ On the other hand, Shang et al. obtained $10: 1[\mathrm{PS}]_{0}:\left[\mathrm{Fe}^{2+}\right]_{0}$ as the optimum ratio for degrading diatrizoate in a CAP system. ${ }^{43}$

In order to study the effects of $[\mathrm{PS}]_{0}$ on TP degradation, different $[\mathrm{PS}]_{0}$ concentrations were used $(0.25$ to $5 \mathrm{mM})$ while maintaining a constant $[\mathrm{PS}]_{0}:\left[\mathrm{Fe}^{2+}\right]_{0}$ ratio of $1: 1$ and $[\mathrm{TP}]_{0}=$ $10 \mathrm{mg} \mathrm{L}^{-1}$ at $T=60^{\circ} \mathrm{C}$. Fig. 3 and Table 3 show that the higher the $[\mathrm{PS}]_{0}$, the greater the observed rate constant $k_{\mathrm{obs}}$. For example, $k_{\mathrm{obs}}$ increased by 32 fold when $[\mathrm{PS}]_{0}$ increased from $0.25 \mathrm{mM}$ to $5.0 \mathrm{mM}$ with good correlation $\left(R^{2}=0.9879\right)$, as shown in the inset of Fig. 3. This observation can be explained by the production of a greater amount of $\mathrm{SO}_{4}{ }^{--}$upon increasing [PS $]_{0}$ (Fig. 3).

3.3.2. Effects of temperature and determination of the activation energy. To study the effects of temperature on TP degradation in TCAP systems, the same conditions as before

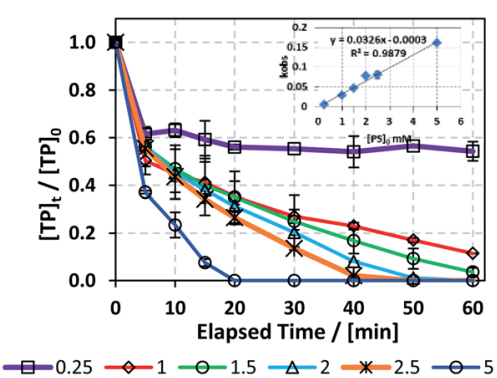

Fig. 3 Optimization of reaction conditions for the TCAP system: effects of $[P S]_{0}=0.25-5 \mathrm{mM}$ on the degradation of TP at a $[P S]_{0^{-}}$ : $\left[\mathrm{Fe}^{2+}\right]_{0}$ ratio of $1: 1$. $[\mathrm{TP}]_{0}=10 \mathrm{mg} \mathrm{L}^{-1}$ for all experiments and $T=$ $60^{\circ} \mathrm{C}$. Error bars are calculated as $\frac{t s}{\sqrt{n}}$, where absent bars fall within the symbols.
Table 3 Optimization of [PS] $]_{0}$ for the TCAP system. The $k_{\text {obs }}$ values and linearity constants of the pseudo-first order equation plot are presented. $[T P]_{0}=10 \mathrm{mg} \mathrm{L}^{-1}$ for all experiments and $T=60^{\circ} \mathrm{C}$

\begin{tabular}{llll}
\hline$[\mathrm{PS}]_{\mathrm{o}}(\mathrm{mM})$ & {$\left[\mathrm{Fe}^{2+}\right]_{\mathrm{o}}(\mathrm{mM})$} & $k_{\mathrm{obs}} \times 10^{-1}\left(\mathrm{~min}^{-1}\right)$ & $R^{2}$ \\
\hline 0.25 & 0.25 & $0.05( \pm 0.02)$ & 0.41 \\
1 & 1 & $0.29( \pm 0.02)$ & 0.93 \\
1.5 & 1.5 & $0.47( \pm 0.03)$ & 0.96 \\
2 & 2 & $0.56( \pm 0.04)$ & 0.96 \\
2.5 & 1.5 & $0.8( \pm 0.1)$ & 0.93 \\
5 & 5 & $1.6( \pm 0.1)$ & 0.98 \\
\hline
\end{tabular}

(Section 3.3.1) were adopted; however, in addition to the temperature reaction variation: $[\mathrm{TP}]_{0}=10 \mathrm{mg} \mathrm{L}^{-1},[\mathrm{PS}]_{0}=$ $\left[\mathrm{Fe}^{2+}\right]_{0}=2 \mathrm{mM}$ and $T=55{ }^{\circ} \mathrm{C}$ to $75{ }^{\circ} \mathrm{C}$. As can be noted in Fig. 4a, complete TP degradation occurred in only $10 \mathrm{~min}$ at $75{ }^{\circ} \mathrm{C}$, while up to $50 \mathrm{~min}$ were required at $60{ }^{\circ} \mathrm{C}$. However, at $55{ }^{\circ} \mathrm{C}$, only partial TP degradation, e.g. $83 \%$, was obtained after $1 \mathrm{~h}$ of reaction. The results also showed that as the temperature increased from $55^{\circ} \mathrm{C}$ to $75{ }^{\circ} \mathrm{C}, k_{\text {obs }}$ increased by 44 fold from 1.9 $( \pm 0.1) \times 10^{-2} \mathrm{~min}^{-1}$ to $8.3( \pm 0.1) \times 10^{-1} \mathrm{~min}^{-1}$.

The TCAP system, like the investigated TAP system (Section 3.1.2), showed excellent fitting with the Arrhenius equation,

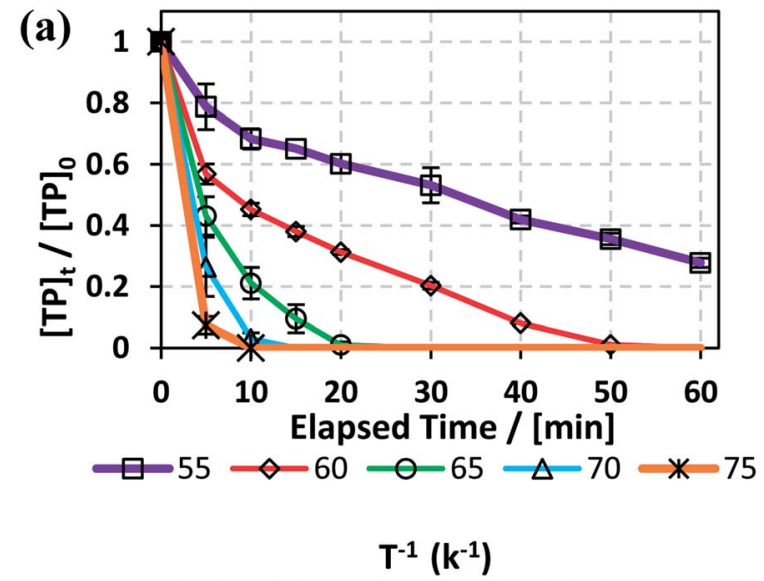

(b) $\quad 0.002850 .00290 .002950 .0030 .003050 .0031$

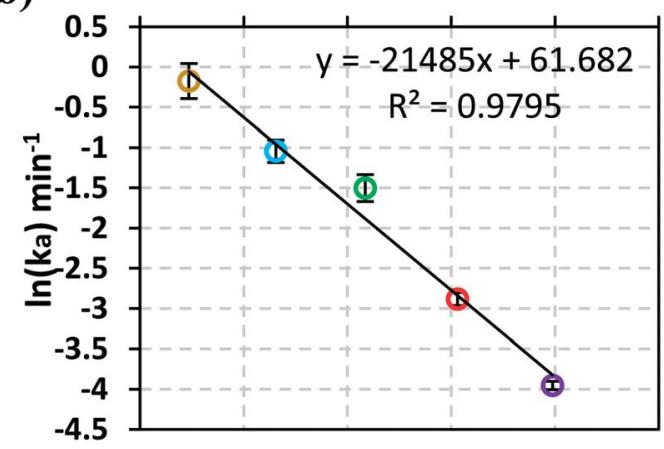

Fig. 4 (a) Effects of temperature on TP degradation in TCAP systems. (b) The corresponding Arrhenius plot of $\ln \left(k_{\mathrm{a}}\right)$ vs. 1/T, showing the equation of linear best fit. Experimental conditions: $[T P]_{0}=10 \mathrm{mg} \mathrm{L}^{-1}$, $[\mathrm{PS}]_{0}=\left[\mathrm{Fe}^{2+}\right]_{0}=2 \mathrm{mM}$ and $T=50-75^{\circ} \mathrm{C}$. Error bars are calculated as $\frac{t s}{\sqrt{n}}$, where absent bars fall within the symbols. 
where the calculated $\ln (A)$ and the apparent activation energy $E_{\mathrm{A}}$ were greater than those calculated in the absence of $\mathrm{Fe}^{2+}$, e.g. 61 $( \pm 5) \mathrm{kJ} \mathrm{mol}^{-1}$ and $178( \pm 14) \mathrm{kJ} \mathrm{mol}^{-1}$, respectively (Fig. 4b). This should not be surprising, as one might expect a lower activation energy in the presence of $\mathrm{Fe}^{2+}$. In fact, $\mathrm{Fe}^{2+}$ does not play the role of a catalyst to decrease $E_{\mathrm{A}}$, nor is it involved in the TP degradation reaction directly. Rather, it plays the role of speeding the production of $\mathrm{SO}_{4}{ }^{--}$from PS upon the chemical activation process (eqn (2)). Additional experiments were carried out at a $10: 1[\mathrm{PS}]_{0}:\left[\mathrm{Fe}^{2+}\right]_{0}$ ratio at different temperatures $\left(40{ }^{\circ} \mathrm{C}, 50{ }^{\circ} \mathrm{C}\right.$ and $\left.60^{\circ} \mathrm{C}\right)$, and the obtained results showed the same outputs. For example, as the reaction temperature increased from $40{ }^{\circ} \mathrm{C}$ to $50{ }^{\circ} \mathrm{C}$ and $60{ }^{\circ} \mathrm{C}$, the \% degradation of TP improved from $29 \%$ to $45 \%$ and $100 \%$, respectively, at $60 \mathrm{~min}$ for $[\mathrm{PS}]_{0}=5 \mathrm{mM}$ (Fig. $6 \mathrm{~S} \dagger$ ). A similar trend was observed for aniline degradation, where $[\mathrm{PS}]_{0}=2.5 \mathrm{mM}$ and zero valent iron $[\mathrm{ZVI}]_{0}=0.3 \mathrm{~g} \mathrm{~L}^{-1}$ resulted in the total elimination of [aniline $]_{0}=0.05 \mathrm{mM}$ in periods of 1 and $2 \mathrm{~h}$ at $T=80{ }^{\circ} \mathrm{C}$ and $60{ }^{\circ} \mathrm{C}$, respectively. ${ }^{44}$

\subsection{Effects of $\mathbf{p H}$ adjustment of the TCAP system}

To study the effects of $\mathrm{pH}$ on the TP degradation process in the TCAP system, the initial $\mathrm{pH}\left(\mathrm{pH}_{\mathrm{i}}\right)$ was adjusted to values of around 3, 5 and 7 using $\mathrm{NaOH}$ solution before the addition of PS. The subsequent PS addition caused a further decrease in $\mathrm{pH}$ $\left(\mathrm{pH}_{\mathrm{PS}}\right.$ ) (Fig. 5 and Table 4). The use of a buffer solution was not possible because an organic buffer would compete with TP on the PS present in the solution; on the other hand, an inorganic buffer, such as phosphate buffer, would cause interference by complexing with $\mathrm{Fe}^{2+} .{ }^{25,34}$ The effect of initial $\mathrm{pH}$ is important to study because the effluent to be treated may contain traces of acid or base from the reactor cleaning process; however, most pharmaceutical production plants use deionized water for preliminary washing of their equipment, so the effluent should contain the highest $[\mathrm{TP}]$ at acidic $\mathrm{pH}$.

It should be noted that the decrease in $\mathrm{pH}$ in the case of the un-adjusted solution is due to two main factors. First, the added $\mathrm{Fe}^{2+}$ solution contains $\mathrm{HCl}$, which was used to increase its

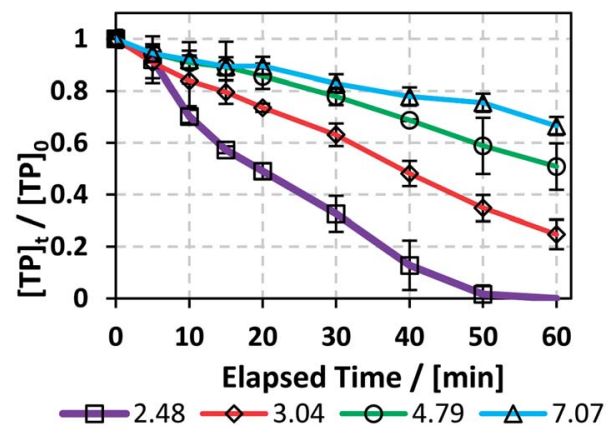

Fig. 5 Effects of $\mathrm{pH}$ adjustment on the degradation of TP in the TCAP system. The $\mathrm{pH}$ values adjusted before PS addition are presented. Experimental conditions: $[\mathrm{TP}]_{0}=10 \mathrm{mg} \mathrm{L}^{-1},[\mathrm{PS}]_{0}=\left[\mathrm{Fe}^{2+}\right]_{0}=2 \mathrm{mM}$ and $T=60^{\circ} \mathrm{C}$. Error bars are calculated as $\frac{t s}{\sqrt{n}}$, where absent bars fall within the symbols.
Table 4 Effects of $\mathrm{pH}$ adjustment on the degradation of TP in the TCAP system. $\mathrm{pH}_{\mathrm{i}}$ represents the $\mathrm{pH}$ adjusted before $\mathrm{PS}$ addition, i.e. the $\mathrm{pH}$ value of the solution before treatment, $\mathrm{pH}_{\mathrm{PS}}$ is the $\mathrm{pH}$ after PS addition, and $\mathrm{pH}_{\mathrm{f}}$ is final $\mathrm{pH}$ at $t=60 \mathrm{~min}$. $k_{\mathrm{obs}}$ is calculated from the pseudo-first order equation plot. Experimental conditions: $[\mathrm{TP}]_{0}=$ $10 \mathrm{mg} \mathrm{L}^{-1},[\mathrm{PS}]_{0}=\left[\mathrm{Fe}^{2+}\right]_{0}=2 \mathrm{mM}$ and $T=60^{\circ} \mathrm{C}$

\begin{tabular}{lcccl}
\hline $\mathrm{pH}$ adjustment & $\mathrm{pH}_{\mathrm{i}}{ }^{a}$ & $\mathrm{pH}_{\mathrm{PS}}{ }^{b}$ & $\mathrm{pH}_{\mathrm{f}}$ & $k_{\text {obs }}\left(\mathrm{min}^{-1}\right)$ \\
\hline- & 2.48 & 2.01 & 2.20 & $4.9( \pm 0.4) \times 10^{-2}$ \\
+ & 3.04 & 2.19 & 2.39 & $1.7( \pm 0.1) \times 10^{-2}$ \\
+ & 4.79 & 2.23 & 2.93 & $1.09( \pm 0.6) \times 10^{-2}$ \\
+ & 7.07 & 2.81 & 5.06 & $6.0( \pm 0.3) \times 10^{-3}$
\end{tabular}

${ }^{a} \mathrm{pH}_{\mathrm{i}}$ is measured before PS addition. ${ }^{b} \mathrm{pH}_{\mathrm{PS}}$ is measured after PS addition.

solubility. Second, PS causes acidification of the medium, as per eqn (7) and (8): $:^{25}$

$$
\begin{array}{r}
\mathrm{S}_{2} \mathrm{O}_{8}{ }^{2-}+\mathrm{H}_{2} \mathrm{O} \rightarrow 2 \mathrm{HSO}_{4}{ }^{-}+\frac{1}{2} \mathrm{O}_{2} \\
\mathrm{HSO}_{4}{ }^{-} \rightarrow \mathrm{SO}_{4}{ }^{2-}+\mathrm{H}^{+},\left(\mathrm{p} K_{\mathrm{a}}=1.92\right)
\end{array}
$$

The results showed that the initial $\mathrm{pH}$ value significantly impacts the degradation process, where $k_{\text {obs }}$ decreased with increasing $\mathrm{pH}_{\mathrm{i}}$ from $4.9( \pm 0.4) \times 10^{-2} \mathrm{~min}^{-1}$ in the case of $\mathrm{pH}_{\mathrm{i}}$ $=2.48$ to $6.0( \pm 0.3) \times 10^{-3} \mathrm{~min}^{-1}$ for $\mathrm{pH}_{\mathrm{i}}=7.07$ (Fig. 5 and Table 4). This can be explained by the fact that at increasing $\mathrm{pH}$, e.g. $\mathrm{pH}$ above 4 , the free iron species in the solution decrease, probably as a result of the formation of Fe(II) complexes..$^{45}$ This was proved experimentally by the formation of a visible precipitate upon $\mathrm{pH}$ increase, e.g. formation of $\mathrm{Fe}(\mathrm{OH})_{2}$ precipitate. As a result, a decrease in the amount of soluble $\mathrm{Fe}^{2+}$ occurs, thereby decreasing the reaction rate between $\mathrm{Fe}^{2+}$ and PS for $\mathrm{SO}_{4}{ }^{--}$production. This was further clarified by comparing the case of $\mathrm{pH}_{\mathrm{i}}$ adjusted to $\mathrm{pH} 7$ in the TCAP system to that of the TAP system at the same $[\mathrm{PS}]_{0}=2 \mathrm{mM}$. In fact, $k_{\mathrm{obs}}$ is $6.0( \pm 0.3) \times 10^{-3}$ for the former and $5.52( \pm 0.08) \times$ $10^{-3} \mathrm{~min}^{-1}$ for the latter (Table $1 \mathrm{~S} \dagger$ ). These values can be explained by the insignificant effects of $\mathrm{Fe}^{2+}$ in the TCAP system adjusted initially to neutral $\mathrm{pH}$. Thus, the studied TCAP system is very sensitive to $\mathrm{pH}$ variations. These results can be compared to a solar $/ \mathrm{Fe}^{2+} / \mathrm{PS}$ system investigated by Nie et al. ${ }^{46} \mathrm{In}$ fact, the authors found a decrease in the degradation rate of chloramphenicol by around $70 \%$ when the reaction $\mathrm{pH}$ increased from 3 to 9.

\subsection{Additive and matrix effects in the TCAP system}

In order to test the effects of $\mathrm{Cl}^{-}, \mathrm{NO}_{3}{ }^{-}$, and HA additives on the degradation rate of TP, the experimental conditions that yielded full TP degradation in $1 \mathrm{~h}$ at $60{ }^{\circ} \mathrm{C}$ were chosen as previously determined (Fig. 3).

3.5.1. Effects of sodium chloride. Different concentrations of saline solutions spiked with TP were investigated in the TCAP system. The resulting TP solutions had $\mathrm{NaCl}$ concentrations of $0,200,2000$ and $20000 \mathrm{mg} \mathrm{L}^{-1}$ to mimic the conditions of 


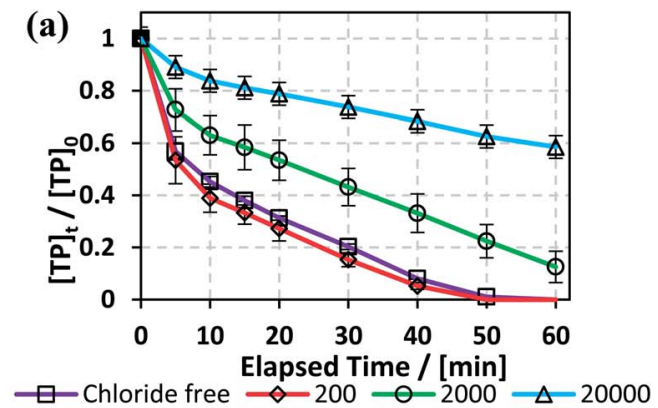

(b)
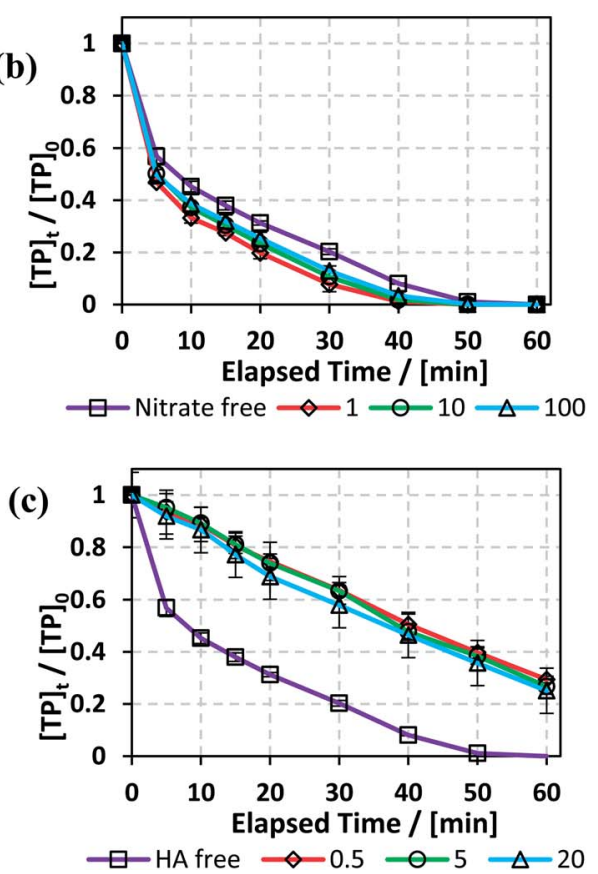

Fig. 6 Effects of (a) $[\mathrm{NaCl}]=200-20000 \mathrm{mg} \mathrm{L}^{-1}$, (b) $\left[\mathrm{NO}_{3}{ }^{-}\right]=1-$ $100 \mathrm{mg} \mathrm{L}^{-1}$, and (c) $[\mathrm{HA}]=0.5-20 \mathrm{mg} \mathrm{L}^{-1}$ on TP degradation in the TCAP system. Experimental conditions: $[\mathrm{PS}]_{0}=\left[\mathrm{Fe}^{2+}\right]_{0}=2 \mathrm{mM}$ and $[\mathrm{TP}]_{0}=10 \mathrm{mg} \mathrm{L}^{-1}$ for all conditions tested. Error bars are calculated as $\frac{t s}{\sqrt{n}}$, where absent bars fall within the symbols.

distilled, fresh, brackish and saline water, respectively, according to Gorrell et al. and EPA data. ${ }^{47,48}$ It should be noted that chloride was present in all solutions at a concentration of $4 \mathrm{mM}$ from $\mathrm{FeCl}_{2}\left(\mathrm{Fe}^{2+}\right.$ source $)$ because $\mathrm{FeCl}_{2}$ was used as a source of $\mathrm{Fe}^{2+}$.

As can be noted from Fig. 6 , the calculated $k_{\text {obs }}$ for the cases of DI and fresh water were almost equal, showing a very slight positive effect of low $[\mathrm{NaCl}]_{0}$ in solution. However, the results also showed that higher $[\mathrm{NaCl}]_{0}$ caused inhibition of the degradation process, where $k_{\text {obs }}$ decreased from $5.6( \pm 0.4) \times$ $10^{-2} \mathrm{~min}^{-1}$ in the case of DI water to $3.0( \pm 0.2) \times 10^{-2} \mathrm{~min}^{-1}$ and $8.0( \pm 0.5) \times 10^{-3} \mathrm{~min}^{-1}$ in the cases of brackish and saline water, respectively (Fig. 6a and Table 5). Moreover, although a decrease in $k_{\text {obs }}$ was noticed for fresh water, almost complete TP degradation was achieved in $60 \mathrm{~min}$. The decrease in $k_{\mathrm{obs}}$ is attributed to the quenching of $\mathrm{SO}_{4}{ }^{--}\left(E^{\circ}=2.437( \pm 0.019) \mathrm{V}\right)$ by $\mathrm{Cl}^{-}$to produce $\mathrm{Cl}^{\circ}\left(E^{\circ}=2.432( \pm 0.018) \mathrm{V}\right)$, which in turn reacts to produce $\mathrm{Cl}_{2}{ }^{--}\left(E^{\circ}=2.126( \pm 0.017) \mathrm{V}\right)$ (eqn (9) and (10)). The latter radical formed has lower redox potential and is thus less effective in terms of oxidation of $\mathrm{TP}$ and its transformation products compared to $\mathrm{SO}_{4}{ }^{\cdot-} \cdot{ }^{49-51}$

Different studies have showed varied effects of $\mathrm{Cl}^{-}$on degradation processes. For example, Fan et al. observed enhancement in the degradation of sulfamethazine, ${ }^{52}$ whereas Norzaee et al. observed inhibition of penicillin G degradation, ${ }^{53}$ both in TAP systems. Wang et al. observed inhibition of acetaminophen degradation at low chloride concentrations and enhancement at high concentrations, while Amasha et al. noted inhibition of ketoprofen degradation, both in $\mathrm{Fe}^{2+} / \mathrm{PS}$ systems. ${ }^{34,54}$ The increased degradation in the presence of $\mathrm{Cl}^{-}$ can be explained by the formation of $\mathrm{Cl}^{\circ}$, which has a redox potential close to that of $\mathrm{SO}_{4}{ }^{-}$, in addition to the formation of reactive $\mathrm{HO}^{*}$ (eqn (9) and (11)-(13))..$^{\mathbf{5 0 , 5 1}}$

$$
\begin{aligned}
& \mathrm{SO}_{4}{ }^{--}+\mathrm{Cl}^{-} \leftrightarrows \mathrm{Cl}^{\cdot}+\mathrm{SO}_{4}{ }^{2-}, k_{\mathrm{f}}=4.7 \times 10^{8}, k_{\mathrm{b}}=2.5 \times 10^{8} \mathrm{M}^{-1} \\
& \mathrm{~s}^{-1} \\
& \mathrm{Cl}^{\cdot}+\mathrm{Cl}^{-} \leftrightarrows \mathrm{Cl}_{2}^{\cdot-}, k_{\mathrm{f}}=8 \times 10^{9} \mathrm{M}^{-1} \mathrm{~s}^{-1}, k_{\mathrm{b}}=4.2 \times 10^{4} \mathrm{~s}^{-1}(10) \\
& \mathrm{Cl}^{-}+\mathrm{H}_{2} \mathrm{O} \leftrightarrows \mathrm{ClOH}^{\cdot-}+\mathrm{H}^{+}, k_{\mathrm{fl}}\left[\mathrm{H}_{2} \mathrm{O}\right]=1.6 \times 10^{5} \mathrm{~s}^{-1}, k_{\mathrm{b}}=2.6 \times \\
& 10^{10} \mathrm{M}^{-1} \mathrm{~s}^{-1} \\
& \mathrm{HOCl}^{--} \leftrightarrows \mathrm{HO}+\mathrm{Cl}^{-}, k_{\mathrm{f}}=6.1 \times 10^{9} \mathrm{~s}^{-1}, k_{\mathrm{b}}=4.3 \times 10^{9} \mathrm{M}^{-1} \\
& \mathrm{~s}^{-1} \\
& \mathrm{HOCl}^{--}+\mathrm{H}^{+} \leftrightarrows \mathrm{H}_{2} \mathrm{O}+\mathrm{Cl}^{\circ}, k_{\mathrm{f}}=2.1 \times 10^{10}, k_{\mathrm{b}}=1.3 \times 10^{3} \mathrm{M}^{-1} \\
& \mathrm{~s}^{-1}
\end{aligned}
$$

3.5.2. Effects of nitrates. Nitrate is one of the most commonly present ions in different water bodies, such as groundwater, due to the excessive use of fertilizers. ${ }^{55}$ Accordingly, the effects of $\left[\mathrm{NO}_{3}{ }^{-}\right]=1,10$ and $100 \mathrm{mg} \mathrm{L}^{-1}$ on TP degradation in the TCAP system were tested. The results showed that the reaction rate increased in the presence of $\left[\mathrm{NO}_{3}{ }^{-}\right]$, where $k_{\text {obs }}$ increased by 6 fold from $5.6( \pm 0.4) \times 10^{-2} \mathrm{~min}^{-1}$ to 1.0 $( \pm 0.1) \times 10^{-1} \mathrm{~min}^{-1}$ in DI media and $\left[\mathrm{NO}_{3}{ }^{-}\right]=1 \mathrm{mg} \mathrm{L}^{-1}$, respectively, and then slightly decreased for $\left[\mathrm{NO}_{3}{ }^{-}\right]=10$ and

Table 5 Effects of $[\mathrm{NaCl}]=200-20000 \mathrm{mg} \mathrm{L}^{-1},\left[\mathrm{NO}_{3}{ }^{-}\right]=1-$ $100 \mathrm{mg} \mathrm{L}^{-1}$, and $[\mathrm{HA}]=0.5-20 \mathrm{mg} \mathrm{L}^{-1}$ on TP degradation in a TCAP system. Experimental conditions: $[\mathrm{PS}]_{0}=\left[\mathrm{Fe}^{2+}\right]_{0}=2 \mathrm{mM}$ and $[\mathrm{TP}]_{0}=$ $10 \mathrm{mg} \mathrm{L}^{-1}$ for all conditions tested. $k_{\mathrm{obs}}$ is obtained as per the pseudofirst order reaction rate model

\begin{tabular}{llll}
\hline Matrix & Unit & $k_{\text {obs }} \times 10^{-2}\left(\mathrm{~min}^{-1}\right)$ & $\mathrm{pH}_{\mathrm{i}} / \mathrm{pH}_{\mathrm{f}}$ \\
\hline No additive & $\mathrm{mg} \mathrm{L}^{-1}$ & $5.6( \pm 0.4)$ & $1.85 / 1.53$ \\
{$[\mathrm{NaCl}]=200$} & & $6.5( \pm 0.5)$ & $1.85 / 1.56$ \\
{$[\mathrm{NaCl}]=2000$} & & $3.0( \pm 0.2)$ & $1.81 / 1.62$ \\
{$[\mathrm{NaCl}]=20000$} & $0.8( \pm 0.05)$ & $1.78 / 1.56$ \\
{$\left[\mathrm{NO}_{3}{ }^{-}\right]=1$} & $10.0( \pm 0.1)$ & $1.81 / 1.71$ \\
{$\left[\mathrm{NO}_{3}{ }^{-}\right]=10$} & $9.0( \pm 0.1)$ & $1.79 / 1.71$ \\
{$\left[\mathrm{NO}_{3}{ }^{-}\right]=100$} & $7.6( \pm 0.7)$ & $1.78 / 1.70$ \\
{$[\mathrm{HA}]=0.5$} & $1.68( \pm 0.07)$ & $1.84 / 1.97$ \\
{$[\mathrm{HA}]=5$} & $2.1( \pm 0.1)$ & $1.83 / 1.95$ \\
{$[\mathrm{HA}]=20$} & $2.2( \pm 0.1)$ & $1.81 / 1.94$
\end{tabular}


Table 6 Physical parameters of the natural water matrices used before and after treatment in the TCAP system. Experimental conditions: [TP $]_{0}=$ $10 \mathrm{mg} \mathrm{L}^{-1},[\mathrm{PS}]_{0}=5 \mathrm{mM}$ and $\left[\mathrm{Fe}^{2+}\right]_{0}=0.5 \mathrm{mM}$

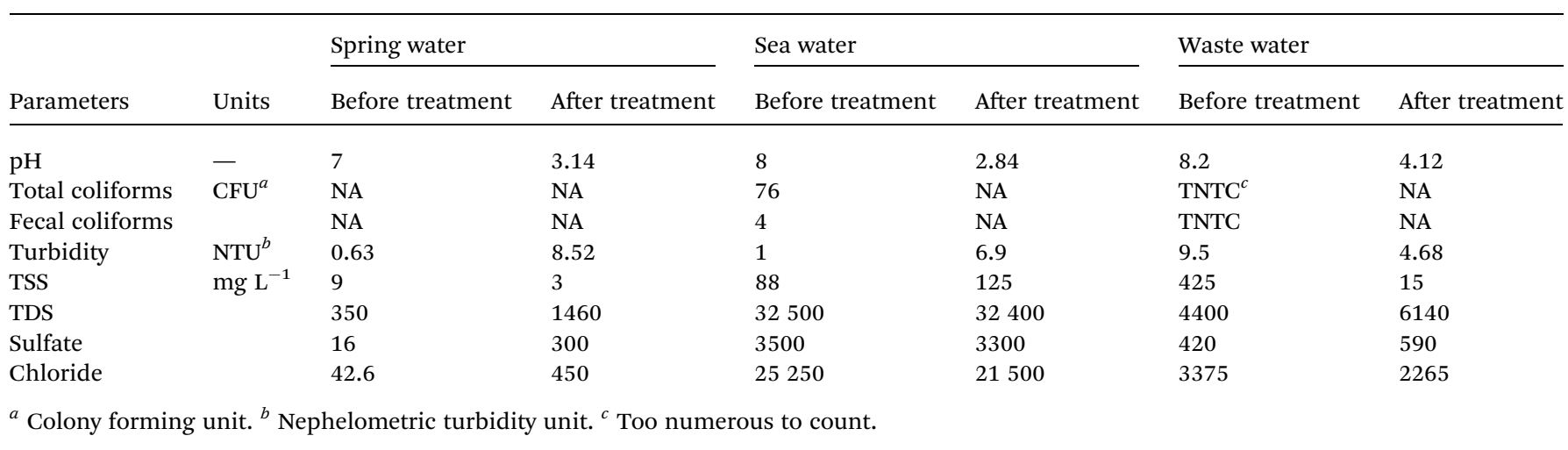

$100 \mathrm{mg} \mathrm{L}^{-1}$ to values of $9.0( \pm 0.1) \times 10^{-2} \mathrm{~min}^{-1}$ and $7.6( \pm 0.7)$ $\times 10^{-2} \mathrm{~min}^{-1}$, respectively (Fig. $6 \mathrm{~b}$ and Table 5).

The increase in TP degradation in the presence of nitrates can be attributed to the formation of $\mathrm{NO}_{3}{ }^{\circ}$, which is considered to have significant oxidation redox potential $\left(E_{1 / 2}^{\mathrm{red}}=2.50 \mathrm{~V}\right)$ and can react with TP. ${ }^{22}$ Therefore, although nitrates react with $\mathrm{SO}_{4}{ }^{\cdot-}$ and quench them, the formation of $\mathrm{NO}_{3}{ }^{\cdot}$ appears to compensate for the decrease in $\left[\mathrm{SO}_{4}{ }^{-}\right]$(eqn (14)). However, the increase in $\left[\mathrm{NO}_{3}^{-}\right]$also results in an increase of $\left[\mathrm{NO}_{3}{ }^{\circ}\right]$, which can subsequently undergo self-quenching reactions; this decreases $\left[\mathrm{NO}_{3}{ }^{\circ}\right]$ and, as a result, decreases the degradation rate. Ghauch et al. also noted an increase in the naproxen degradation rate by $154.3 \%$ in the presence of $\left[\mathrm{NO}_{3}^{-}\right]=5 \mathrm{mg} \mathrm{L}^{-1}$ in a TAP system. ${ }^{26}$

$$
\mathrm{SO}_{4}{ }^{\cdot-}+\mathrm{NO}_{3}^{-} \rightarrow \mathrm{SO}_{4}{ }^{2-}+\mathrm{NO}_{3} \cdot
$$

3.5.3. Effects of humic acid (HA). One widely present type of natural organic matter (NOM) is humic acid (HA). ${ }^{45}$ TP degradation in the TCAP system was studied in the presence of $[\mathrm{HA}]_{0}=0.5,5$ and $20 \mathrm{mg} \mathrm{L}^{-1}$, which are in the typical naturally existing range. ${ }^{56}$ The results show that HA inhibited the degradation rate, where $k_{\text {obs }}$ decreased by almost 3 fold when $[\mathrm{HA}]_{0}=$ $0.5 \mathrm{mg} \mathrm{L}^{-1}$ compared to HA-free medium. After that, the increase in $[\mathrm{HA}]_{0}$ caused no significant change in $k_{\text {obs }}$ (Fig. $6 \mathrm{c}$ and Table 5). The inhibition in TP degradation can be explained by the competitiveness of active radicals, where NOM quenches $\mathrm{SO}_{4}{ }^{\cdot-}$ due to the presence of electron-rich sites. ${ }^{57}$ Liu et al. noted a significant decrease in reaction rate with increasing [HA] during sulfachloropyridazine degradation in a TAP system. ${ }^{57}$ Amasha et al. noted enhanced ketoprofen degradation in a CAP system at $[\mathrm{HA}]_{0}=0.5$, which was explained by the possible reductive ability of HA towards transition metals which, in the case of a CAP system, can regenerate $\mathrm{Fe}^{2+}$ from $\mathrm{Fe}^{3+} \cdot{ }^{34,58}$ Thus, for the case of TP degradation in the TCAP system, the cease in the decrease in $k_{\mathrm{obs}}$ with increasing [HA] $]_{0}$ can be explained by the counter effects of $\mathrm{HA}$; at higher concentrations, HA contributes more to the re-generation of $\mathrm{Fe}^{2+}$, which counteracts its radical-quenching properties.

\subsection{Case of natural water matrices: spring, sea, and waste water in the TCAP system}

The degradation of TP was studied in media of natural sea, spring and waste water (SW, SpW and WW) obtained from locations at coordinates of $33^{\circ} 44^{\prime} 17.9^{\prime \prime} \mathrm{N} \quad 35^{\circ} 34^{\prime} 12.5^{\prime \prime} \mathrm{E}$, $33^{\circ} 54^{\prime} 11.1^{\prime \prime} \mathrm{N} 35^{\circ} 28^{\prime} 44.8^{\prime \prime} \mathrm{E}$ and $33^{\circ} 54^{\prime} 08.2^{\prime \prime} \mathrm{N} 35^{\circ} 29^{\prime} 05.0^{\prime \prime} \mathrm{E}$, respectively. The experimental conditions are as follows: $[\mathrm{PS}]_{0}=$ $5 \mathrm{mM},\left[\mathrm{Fe}^{2+}\right]_{0}=0.5 \mathrm{mM}$, and TP were added in adequate amounts to each water medium so that $[\mathrm{TP}]_{0}=10 \mathrm{mg} \mathrm{L}^{-1}$. A $[\mathrm{PS}]_{0}:\left[\mathrm{Fe}^{2+}\right]_{0}$ ratio of $10: 1$ was used instead of the optimum obtained ratio of $1: 1$ in order to decrease the use of $\mathrm{Fe}^{2+}$, e.g. $\mathrm{Fe}(\mathrm{OH})_{2}$ in neutral media. ${ }^{45}$ These conditions were adopted because natural water matrices are buffered to around neutral $\mathrm{pH}$ (Table 6), mainly because of the presence of bicarbonate. The results showed that TP degradation was inhibited in the three tested cases compared to the DI matrix case, where $k_{\mathrm{obs}}=$ $1.5( \pm 0.1) \times 10^{-1} \mathrm{~min}^{-1}$, with WW showing $\sim 570$ fold inhibition in terms of $k_{\mathrm{obs}}=2.6( \pm 0.6) \times 10^{-4} \mathrm{~min}^{-1}$, followed by $\mathrm{SpW} \sim 14$ fold and SW $\sim 10$ fold, $k_{\mathrm{obs}}=1.1( \pm 0.1) \times 10^{-2}$ and $1.54( \pm 0.09) \times 10^{-2} \mathrm{~min}^{-1}$, respectively (Fig. 7).

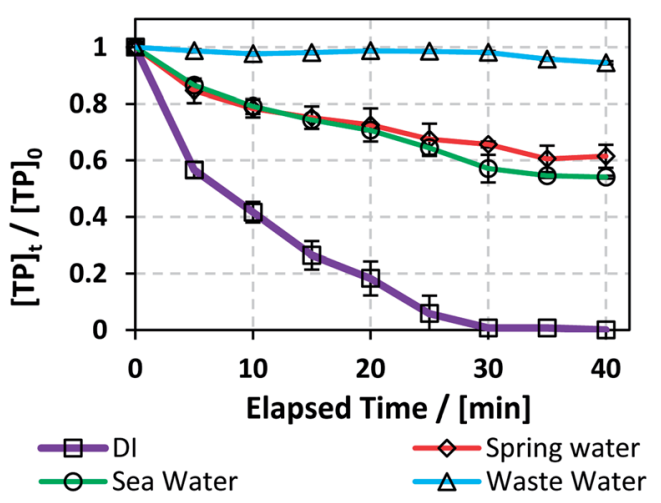

Fig. 7 Degradation of TP in real water samples: spring, sea and waste water. Experimental conditions: $[\mathrm{TP}]_{0}=10 \mathrm{mg} \mathrm{L}^{-1},[\mathrm{PS}]_{0}=5 \mathrm{mM}$ and $\left[\mathrm{Fe}^{2+}\right]_{0}=0.5 \mathrm{mM}$. Error bars are calculated as $\frac{t s}{\sqrt{n}}$, where absent bars fall within the symbols. 


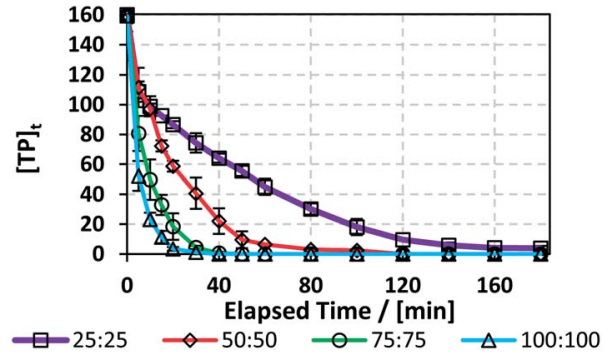

Fig. 8 Degradation of TP by TCAP in real pharmaceutical effluent containing $[\mathrm{TP}]_{0}=160 \mathrm{mg} \mathrm{L}^{-1}$. Experimental conditions: $[\mathrm{PS}]_{0}=25$, 50, 75 and $100 \mathrm{mM},[\mathrm{PS}]_{0}:\left[\mathrm{Fe}^{2+}\right]_{0}$ ratio $=1: 1$, and $T=60{ }^{\circ} \mathrm{C}$. Error bars are calculated as $\frac{t s}{\sqrt{n}}$, where absent bars fall within the symbols.

One reason for the inhibition of the degradation of TP in the three investigated cases is the neutral to slightly basic $\mathrm{pH}$ values (7 to 8.2); this $\mathrm{pH}$ range causes the complexation and precipitation of $\mathrm{Fe}^{2+}$, e.g. as $\mathrm{Fe}(\mathrm{OH})_{2}$, where natural water media act as buffer solutions compared to DI medium, which becomes acidic $\left(\mathrm{pH}_{\mathrm{i}} \approx 2\right)$ immediately after the addition of $\mathrm{PS}$ and $\mathrm{Fe}^{2+}$ solutions. The inhibition was the highest in the case of the WW matrix, where WW possessed the highest values of total and fecal coliforms, chlorides, turbidity and total suspended and dissolved solids among the three studied matrices. The organic and inorganic material present in WW competes with TP in reacting with $\mathrm{SO}_{4}{ }^{-}$, thus inhibiting $\mathrm{TP}$ degradation. Additionally, chlorides acted as quenchers in the studied TCAP system (Section 3.5.1), and WW showed the highest $\left[\mathrm{Cl}^{-}\right]$. It should be noted that total elimination of coliforms was observed in the WW and SW (Table 6) systems; this is probably due to the heat factor in addition to the activity of the $\mathrm{SO}_{4}{ }^{--}$present. Effluents of pharmaceutical production plants, after discharge, may be mixed with several water matrices with different properties. In addition, the water used for initial cleaning operations may be of natural origin and not DI water. The results presented in this section show that it is crucial to clean mixing reactors in pharmaceutical production facilities with distilled water whenever possible and to treat the effluent mixture before its release into the environment. A great decrease in degradation rates in waste water was also observed by Ghauch's research group upon degradation of chloramphenicol and ketoprofen in UV/PS systems. ${ }^{22,34}$

\subsection{Case study: real factory effluent}

3.7.1. Effects of $[\mathbf{P S}]_{0}$. The efficiency of the TCAP system was tested on a real pharmaceutical factory effluent solution containing TP in addition to other excipients. The effluent samples were collected from a local production facility that produces a syrup containing TP. The production process consists of mixing TP and other excipients in a $1000 \mathrm{~L} 316$ SS container, after which the mixture is pumped through a filter press into $100 \mathrm{~L} 316$ SS containers. Waste water samples were collected by washing the SS reactor and the filter press with distilled water. The resulting factory effluent solution contained $[\mathrm{TP}]_{0}=160 \mathrm{mg} \mathrm{L}^{-1}$ (Fig. 8S $\dagger$ ). To account for the high $[\mathrm{TP}]_{0}$ effluent content, [PS $]_{0}$ was tested at 25, 50, 75 and $100 \mathrm{mM}$ utilizing the optimum $[\mathrm{PS}]_{0}:\left[\mathrm{Fe}^{2+}\right]_{0}$ ratio of $1: 1$ and $T=60^{\circ} \mathrm{C}$.

The results showed that a higher $[\mathrm{PS}]_{0}$ caused faster degradation, where total TP elimination was observed within $40 \mathrm{~min}$ in the case of $[\mathrm{PS}]_{0}=\left[\mathrm{Fe}^{2+}\right]_{0}=100 \mathrm{mM}$ and within $180 \mathrm{~min}$ for $[\mathrm{PS}]_{0}=\left[\mathrm{Fe}^{2+}\right]_{0}=25 \mathrm{mM}$ (Fig. 8 and Table 7 ). To compare the degradation of TP in DI and in the factory effluent mixture, $k_{\mathrm{obs}}$ can be compared in cases of similar $[\mathrm{PS}]_{0} /[\mathrm{TP}]_{0}$ molar ratios. As such, for the case of $[\mathrm{TP}]_{0}=10 \mathrm{mg} \mathrm{L}^{-1}(0.0555 \mathrm{mM})$ and $[\mathrm{PS}]_{0}=$ $\left[\mathrm{Fe}^{2+}\right]_{0}=1.5 \mathrm{mM}$ in DI, $[\mathrm{PS}]_{0} /[\mathrm{TP}]_{0}=27$, while for the case of $[\mathrm{TP}]_{0}=160 \mathrm{mg} \mathrm{L}^{-1}$ and $[\mathrm{PS}]_{0}=\left[\mathrm{Fe}^{2+}\right]_{0}=25 \mathrm{mM}$ in factory effluent, $[\mathrm{PS}]_{0} /[\mathrm{TP}]_{0}=28$. The corresponding $k_{\text {obs }}$ decreased by 2 fold from $0.29( \pm 0.02) 10^{-1}$ to $1.4( \pm 0.1) \times 10^{-2} \mathrm{~min}^{-1}$. Thus, the TP degradation in factory effluent is less efficient than in DI medium. This can be attributed to the presence of excipients, such as potassium sorbate, sorbitol, ethanol, vanillin and saccharine, as provided by the manufacturer. Those can compete with TP in reacting with the active SRs. It should be noted that the efficiency of the TCAP system would have decreased if natural water was used to rinse the mixing reactor instead of DI water (Section 3.3.5); thus, it is crucial for industries to utilize adequate amounts of distilled (DI) water in rinsing apparatuses and tools used during syntheses and mixing processes for efficient and cost-effective effluent treatment.

3.7.2. Economic study. The cost of factory effluent treatment utilizing the TCAP system was estimated. The electric energy required to heat the solution in addition to the reagent price were considered to be the main contributors to the total cost of operation (eqn (15)).

Total system cost $\left(\$\right.$ per $\left.\mathrm{m}^{3}\right)=$ electrical energy cost + reagent cost

Electric energy per order $\left(E_{\mathrm{EO}}\right)$ was defined as the electric energy required to degrade contaminants by one order of magnitude, for example from $10 \mathrm{mg} \mathrm{L}^{-1}$ to $1 \mathrm{mg} \mathrm{L}{ }^{-1}$, in one cubic meter of contaminated water or air; this was calculated using eqn (16) for a batch system. ${ }^{59}$

$$
E_{\mathrm{EO}}=\frac{P \times t \times 1000}{V \times \log \left(\frac{C_{\mathrm{i}}}{C_{\mathrm{f}}}\right)}
$$

where $P$ is the power supplied to the system in $\mathrm{kW}, t$ is the duration of the treatment in hours, $V$ is the volume treated in $\mathrm{L}$, $C_{\mathrm{i}}$ and $C_{\mathrm{f}}$ are the initial and final concentrations, respectively,

Table 7 Degradation of TP by TCAP in real pharmaceutical effluent containing $[\mathrm{TP}]_{0}=160 \mathrm{mg} \mathrm{L}^{-1}$. Experimental conditions: $[\mathrm{PS}]_{0}=25-$ $100 \mathrm{mM},[\mathrm{PS}]_{0}:\left[\mathrm{Fe}^{2+}\right]_{0}$ ratio of $1: 1$, and $T=60^{\circ} \mathrm{C}$. $k_{\mathrm{obs}}$ is calculated for the pseudo-first order reaction rate

\begin{tabular}{lllll}
\hline$[\mathrm{PS}]_{\mathrm{o}} \mathrm{mM}$ & {$\left[\mathrm{Fe}^{2+}\right]_{0} \mathrm{mM}$} & $T^{\circ} \mathrm{C}$ & $k_{\mathrm{obs}} \mathrm{min}^{-1}$ & $\mathrm{pH}_{\mathrm{i}} / \mathrm{pH}_{\mathrm{f}}$ \\
\hline 25 & 25 & 60 & $1.4( \pm 0.1) \times 10^{-2}$ & $1.17 / 1.08$ \\
50 & 50 & & $4.5( \pm 0.2) \times 10^{-2}$ & $0.85 / 0.78$ \\
75 & 75 & & $1.16( \pm 0.05) \times 10^{-1}$ & $0.67 / 0.60$ \\
100 & 100 & & $1.65( \pm 0.09) \times 10^{-1}$ & $0.58 / 0.48$
\end{tabular}


Table 8 Treatment costs of pharmaceutical effluent contaminated with TP using a TCAP system. The calculations of total system cost for different TP degradation conditions in pharmaceutical effluent are based on electricity price rates in the US and in Lebanon. Experimental conditions: $[\mathrm{TP}]_{0}=160 \mathrm{mg} \mathrm{L}^{-1},[\mathrm{PS}]_{0}=25,50,75$ and $100 \mathrm{mM},[\mathrm{PS}]_{0}:\left[\mathrm{Fe}^{2+}\right]_{0}$ ratio of $1: 1$, and $T=60^{\circ} \mathrm{C}$

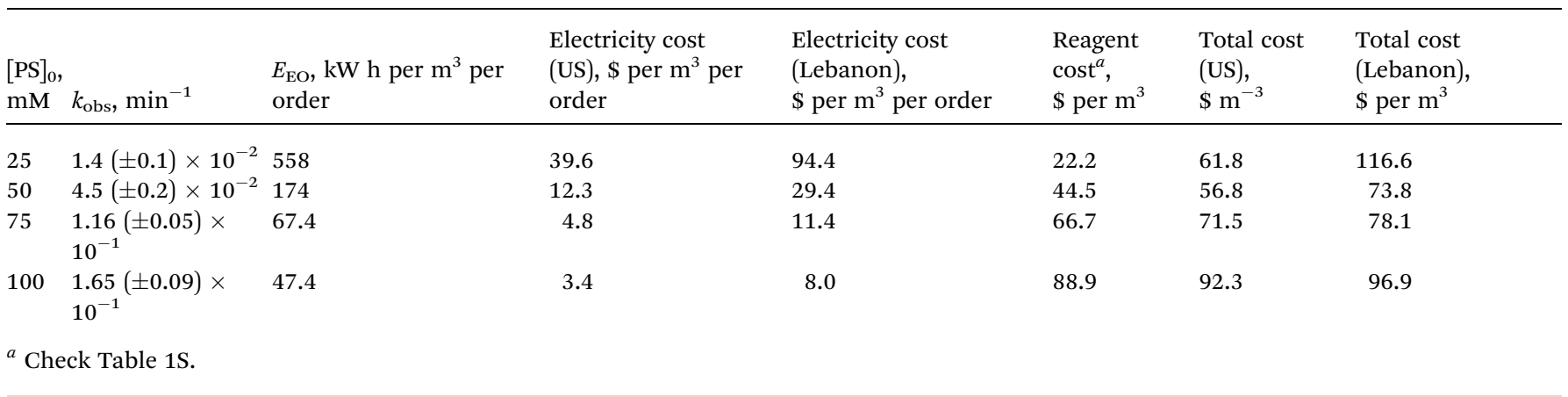

and 1000 is a conversion factor from $\mathrm{L}$ to $\mathrm{m}^{3}$. Thus, $E_{\mathrm{EO}}$ is obtained in $\mathrm{kW}$ h per $\mathrm{m}^{3}$ per order. Additionally, eqn (16) was simplified by substituting the first-order reaction rate eqn (17) in eqn (16) and changing the unit of time. Thus, the following simplification was performed (eqn (16)-(19)):

$$
\begin{gathered}
\log \frac{C_{\mathrm{i}}}{C_{\mathrm{f}}}=0.4343 \times k_{\mathrm{obs}} \times t \\
E_{\mathrm{EO}}=\frac{P \times t \times 1000}{V \times 0.4343 \times k_{\mathrm{obs}} \times t \times 60} \\
E_{\mathrm{EO}}=\frac{38.4 \times P}{V \times k_{\mathrm{obs}}}
\end{gathered}
$$

The resulting simplified eqn (19) shows $P$ in $\mathrm{kW}, V$ in $\mathrm{L}$, and $k_{\text {obs }}$ in $\min ^{-1}{ }^{-59}$ Power was calculated based on the energy and time needed to heat the reactors. The energy required for this heating was calculated using eqn (20), where $Q$ is the energy in J, $m$ is the mass of water in $\mathrm{g}(200 \mathrm{~g}), C$ is the specific heat capacity of water $\left(4.186 \mathrm{~J} \mathrm{~g} \mathrm{~g}^{-1}{ }^{\circ} \mathrm{C}^{-1}\right)$, and $\Delta T\left(35^{\circ} \mathrm{C}\right)$ is the temperature difference for heating from $25{ }^{\circ} \mathrm{C}$ to $60{ }^{\circ} \mathrm{C}$. $Q$ was found to be $29.3 \mathrm{~kJ}$.

$$
Q=m C \Delta T
$$

Power was calculated utilizing eqn (21), where $t$ is the time in seconds needed to heat the solution to the desired temperature. Experimentally, $12 \mathrm{~min}$ were required to heat the $200 \mathrm{~mL}$ reactor from room temperature to $60^{\circ} \mathrm{C}$. Thus, $P=0.122 \mathrm{~kW}$.

$$
P=\frac{Q}{t}
$$

The $E_{\mathrm{EO}}$ was calculated for each of the four different $[\mathrm{PS}]_{0}$ values, and the results are presented in Table 8. The electrical energy cost was estimated utilizing electricity cost rates in Lebanon, with the Electricite du Liban (EDL) average rate of 255 LBP per $\mathrm{kW}$ per $\mathrm{h}$ equivalent to $0.169 \$$ per $\mathrm{kW}$ per $\mathrm{h}$ at the current conversion rate, ${ }^{60,61}$ as well as in the US, where the average electricity cost rate for the industrial sector is $0.0709 \$$ per $\mathrm{kW}$ per $\mathrm{h}$. The costs of the reagents were calculated using wholesale prices in every case (Table S1†). The total system cost can thus be obtained (eqn (15)) and is presented in detail in Fig. 9. It was observed that as $[\mathrm{PS}]_{0}$ increases, the reagent cost increases, while the electric cost due to heating decreases. Consequently, the choice of $[\mathrm{PS}]_{0}$ for the treatment of factory effluent can be based on the estimated total cost, where the case of $[\mathrm{PS}]_{0}=50 \mathrm{mM}$ gave the lowest total cost of 56.8 and $73.8 \$$ per $\mathrm{m}^{3}$ based on electricity prices in the US and in Lebanon, respectively (Fig. 9 and Table 8).

Amasha et al. obtained a total cost of $44.414 \$$ per $^{3}$ for degradation of ketoprofen $\left(7.87 \mu \mathrm{M}, 2.00 \mathrm{mg} \mathrm{L}^{-1}\right)$ in a TAP system, with $[\mathrm{PS}]_{0}=1 \mathrm{mM}$ and $T=60^{\circ} \mathrm{C}^{34}$ The lower total cost obtained by the mentioned study can be attributed to the fact that no $\mathrm{Fe}^{2+}$ was used, so the reagent price was lower; in addition, the degradation was performed in DI and not in factory effluent, where competitive reactions take place between $\mathrm{SO}_{4}{ }^{-}$ and the excipients present (Section 3.7.1).

\subsection{Effects of $\mathrm{MeOH}$ and TBA quenchers}

Radical scavenging by methanol $(\mathrm{MeOH})$ and tert-butyl-alcohol (TBA) was tested in the TCAP system to determine the effectiveness of the produced $\mathrm{SO}_{4}{ }^{--}$and $\mathrm{HO}^{\circ}$ in the degradation of TP. Different concentrations of $\mathrm{MeOH}$ and TBA $(400,800 \mathrm{mM})$ were added separately to reactors containing $[\mathrm{TP}]_{0}=10 \mathrm{mg} \mathrm{L}^{-1}$

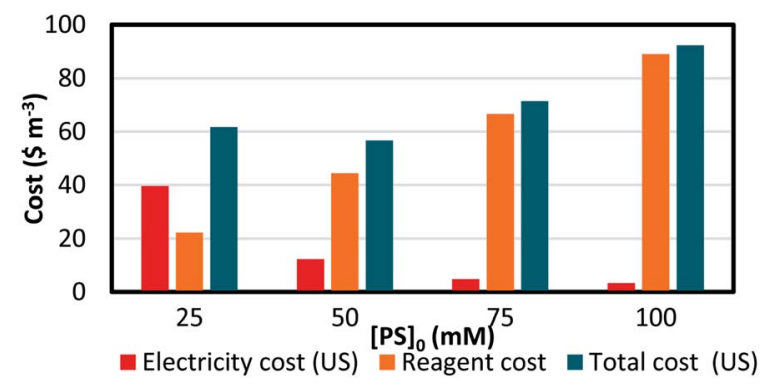

Fig. 9 Treatment cost of pharmaceutical effluent contaminated with TP using a TCAP system. The electricity, reagent and total costs are presented (based on US electricity cost). Experimental conditions: $[\mathrm{TP}]_{0}=160 \mathrm{mg} \mathrm{L}^{-1},[\mathrm{PS}]_{0}=25-100 \mathrm{mM},[\mathrm{PS}]_{0}:\left[\mathrm{Fe}^{2+}\right]_{0}$ ratio of $1: 1$ and $T=60^{\circ} \mathrm{C}$. 

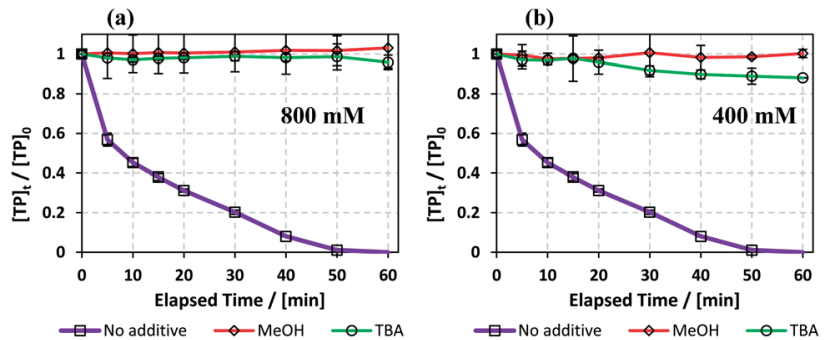

Fig. 10 (a) Effects of $\mathrm{MeOH}$ and TBA quenchers on TP degradation in the TCAP system. Experimental conditions: $[\mathrm{TP}]_{0}=10 \mathrm{mg} \mathrm{L}^{-1},[\mathrm{PS}]_{0}=$ $\left[\mathrm{Fe}^{2+}\right]_{0}=2 \mathrm{mM}$. $[\mathrm{MeOH}]=[\mathrm{TBA}]=$ (a) 800 and (b) $400 \mathrm{mM}$ and $T=$ $60^{\circ} \mathrm{C}$. Error bars are calculated as $\frac{t s}{\sqrt{n}}$, where absent bars fall within the symbols.

and $[\mathrm{PS}]_{0}=\left[\mathrm{Fe}^{2+}\right]_{0}=2 \mathrm{mM}$. The experiments were conducted in tight reactors using rubber stoppers in order to prevent substantial loss of $\mathrm{MeOH}\left(k_{\mathrm{H}}^{\circ}=230 \mathrm{~mol} \mathrm{~kg}^{-1} \mathrm{bar}^{-1}\right)$ and TBA $\left(k_{\mathrm{H}}^{\circ}=83 \mathrm{~mol} \mathrm{~kg}^{-1}\right.$ bar $\left.^{-1}\right)$ from the reactor due to heat. ${ }^{62}$ It is known that $\mathrm{MeOH}$ quenches both $\mathrm{SO}_{4}{ }^{-}$and $\mathrm{HO}^{-}$radicals, whereas TBA mainly quenches $\mathrm{OH}^{*} .^{22}$

Fig. 10 shows that $\mathrm{MeOH}$ and TBA caused increased inhibition as their concentrations increased. This is due to the increase in competition between the quenchers and TP to react with the radicals present in the medium. Wang et al. also obtained a positive correlation between inhibition extent and the concentrations of TBA and $\mathrm{MeOH}$ used in a TAP system..$^{63}$ In the case of $800 \mathrm{mM}$ quenchers used (quencher/PS: 400/1), TBA and $\mathrm{MeOH}$ caused almost total quenching due to their high concentrations. However, when $400 \mathrm{mM}$ quenchers were used (Quencher/PS: 200/1), MeOH caused slightly more quenching than TBA. We can deduce that $\mathrm{HO}^{\circ}$ is the major reactive species when degrading TP in a TCAP system.

\subsection{Suggested degradation pathway}

A theoretical study of the degradation pathway utilizing frontier orbitals and charge distribution was conducted. Frontier molecular orbital theory shows that electrophilic reactions are more likely to occur for atoms with higher values of the highest

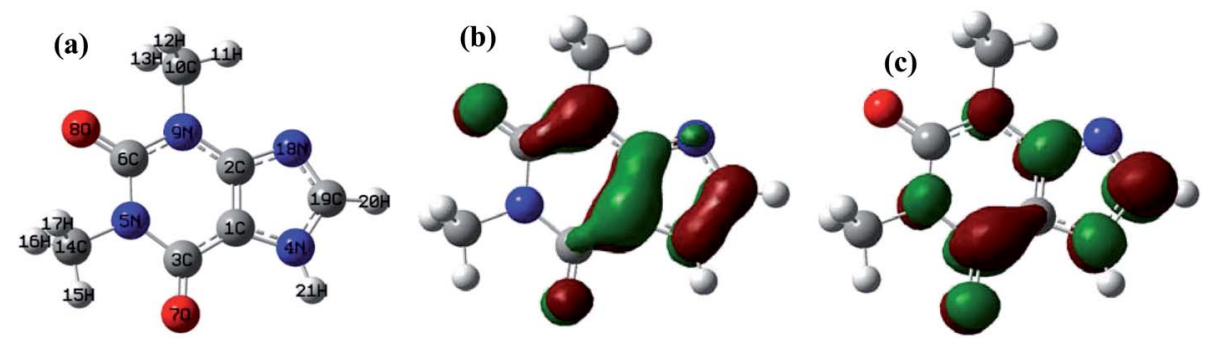

Fig. 11 (a) TP atomic labeling and numbering. Isodensity surfaces of the (b) HOMO and (c) LUMO of TP with isovalues of 0.05 .

Table 9 The computed values of the FEDs for the HOMO and LUMO in addition to the Mulliken charge distributions

\begin{tabular}{|c|c|c|c|c|}
\hline $1 \mathrm{C}$ & 0.27 & 0.45 & 0.08 & 0.35 \\
\hline $2 \mathrm{C}$ & 0.23 & 0.19 & 0.27 & 0.11 \\
\hline $4 \mathrm{~N}$ & 0.17 & 0.13 & 0.21 & -0.21 \\
\hline $5 \mathrm{~N}$ & 0.05 & 0.01 & 0.10 & -0.25 \\
\hline $6 \mathrm{C}$ & 0.02 & 0.04 & 0.01 & 0.56 \\
\hline $9 \mathrm{~N}$ & 0.25 & 0.38 & 0.11 & -0.26 \\
\hline $10 \mathrm{C}$ & 0.01 & 0.01 & 0.01 & -0.21 \\
\hline $11 \mathrm{H}$ & 0.00 & 0.00 & 0.00 & 0.14 \\
\hline $12 \mathrm{H}$ & 0.01 & 0.02 & 0.00 & 0.14 \\
\hline $13 \mathrm{H}$ & 0.01 & 0.02 & 0.00 & 0.14 \\
\hline $14 \mathrm{C}$ & 0.00 & 0.00 & 0.00 & -0.15 \\
\hline $19 \mathrm{C}$ & 0.28 & 0.19 & 0.36 & 0.29 \\
\hline $20 \mathrm{H}$ & 0.00 & 0.00 & 0.00 & 0.23 \\
\hline $21 \mathrm{H}$ & 0.00 & 0.00 & 0.00 & 0.25 \\
\hline $22 \mathrm{H}$ & - & - & - & - \\
\hline
\end{tabular}




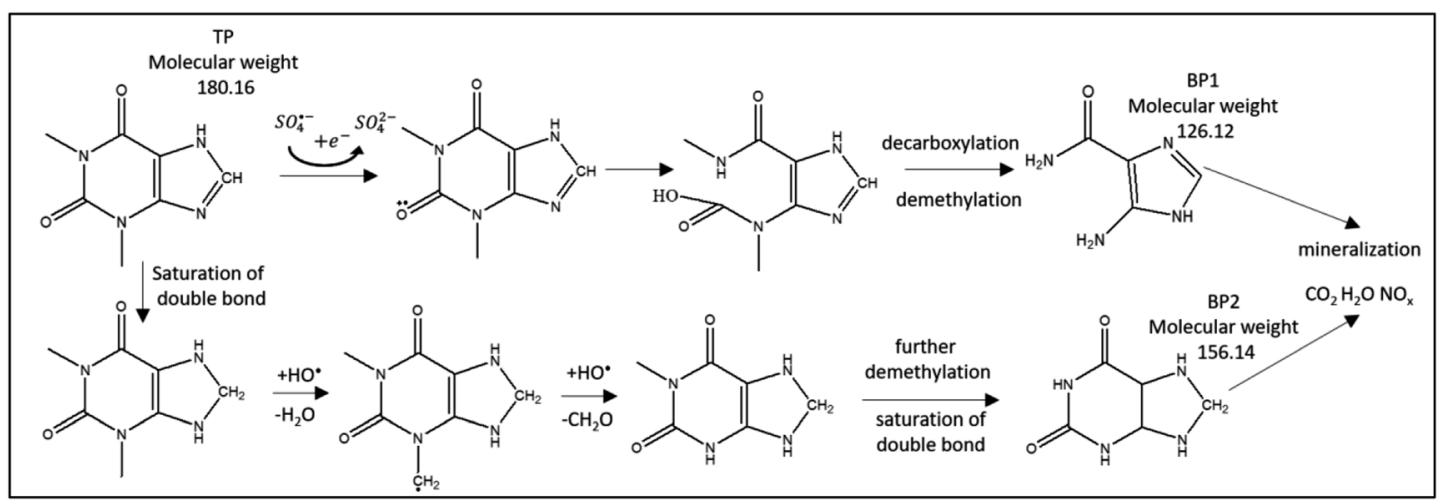

Fig. 12 Suggested TP degradation pathway by $\mathrm{SO}_{4}{ }^{-}-$and $\mathrm{HO}^{\circ}$. Two detected by-products, $\mathrm{BP} 1$ and $\mathrm{BP} 2$, are included.

occupied molecular orbital (HOMO), while nucleophilic reactions are prone to occur for atoms with higher values of the lowest unoccupied molecular orbital (LUMO). ${ }^{64}$ Consequently, several studies suggest that atoms with a higher $2 \mathrm{FED}_{\text {Hомо }}{ }^{2}$ are more easily oxidized, and those with a higher $\mathrm{FED}_{\mathrm{HOMO}^{2}}+$ $\mathrm{FED}_{\mathrm{LUMO}^{2}}$ are more susceptible to addition reactions..$^{65-67}$ The $2 \mathrm{FED}_{\mathrm{HOMO}^{2}}, 2 \mathrm{FED}_{\mathrm{HOMO}^{2}}$, and Mulliken charge distributions were calculated for $\mathrm{TP}$ and are presented along with the atom numbering and the isodensity surfaces of frontier molecular orbital theory in Fig. 11 and Table 9. For TP, 1C showed the highest $2 \mathrm{FED}_{\mathrm{HOMO}^{2}}$, followed by $9 \mathrm{~N}, 8 \mathrm{O}, 2 \mathrm{C}, 19 \mathrm{C}, 3 \mathrm{C}$ and $7 \mathrm{O}$. Therefore, attack by oxidants is expected to occur readily on 1C, $9 \mathrm{~N}$ and 8O. Also, 3C showed the highest $\mathrm{FED}_{\mathrm{HOMO}^{2}}+\mathrm{FED}_{\mathrm{LUMO}^{2}}$, followed by 19C, 1C, 9N, 2C, 7O and 4N. Thus, addition reactions will mostly take place at $1 \mathrm{C}, 19 \mathrm{C}$ and $3 \mathrm{C}$; however, it was noted that $19 \mathrm{C}$ is the least sterically hindered of the three atoms. Thus, addition reactions are expected to occur more readily at $19 \mathrm{C}$, such as the formation of hydroxylated products at this site. It is known that $\mathrm{HO}^{\circ}$ performs $\mathrm{H}$ abstraction and $\mathrm{SO}_{4}{ }^{--}$acts selectively as an electron transfer reactant. ${ }^{68}$ According to the obtained Mulliken charge distributions, electrons are mostly abstracted from $7 \mathrm{O}$ and 80 because they show the most negative charges (Table 9). These results were used to suggest a degradation mechanism (Fig. 12).

LC/MS/MS was used to identify the by-products of TP degradation. Fig. $8 \mathrm{~S} \uparrow$ shows two identified by-products termed BP1 (molecular weight $126.12 \mathrm{~g} \mathrm{~mol}^{-1}$ ) and BP2 (molecular weight $156.14 \mathrm{~g} \mathrm{~mol}^{-1}$ ). The extracted ion chromatograms of BP1 and BP2 showed that the intensities of their peaks constantly increased with time, which proves that these byproducts are formed throughout the degradation reaction (Fig. $8 \mathrm{~S} \dot{\dagger}$ ). It was noted that the intensity of BP1 is higher, which suggests that it is more prevalent than BP2.

Fig. 12 presents the suggested degradation pathway based on the results obtained from theoretical studies and LC/MS/MS results. Electron abstraction is expected on the oxygen group (8O, Fig. 11) by $\mathrm{SO}_{4}{ }^{--}$. Attack of $\mathrm{SO}_{4}{ }^{--}$and $\mathrm{HO}^{\circ}$ is expected on the 6-membered ring, where ring opening occurs with the formation of carboxylic groups. This is followed by loss of $\mathrm{CO}_{2}$ and de-methylation on the $5 \mathrm{~N}$ and $9 \mathrm{~N}$ sites. As a result, BP1 is obtained.
Demethylation is initiated by hydrogen abstraction at $10 \mathrm{C}$ and $14 \mathrm{C}$, which is followed by $\mathrm{HO}^{\circ}$ attack. BP2 is formed through demethylation and saturation of double bonds. Ultimately, mineralization is expected, which was obtained in similar AOP studies. ${ }^{69,70}$

\section{Conclusions}

In this study, TP degradation was tested in systems of TAP, CAP and TCAP. TAP resulted in incomplete (60\%) TP degradation at $t=60 \mathrm{~min}$ for $[\mathrm{PS}]_{0}=5 \mathrm{mM}$ and $T=60^{\circ} \mathrm{C}$. The CAP system was not effective at room temperature, where a maximum of $5 \% \mathrm{TP}$ degradation was observed at $t=60 \mathrm{~min}$ for $[\mathrm{PS}]_{0}=\left[\mathrm{Fe}^{2+}\right]_{0}=0.25 \mathrm{mM}$. To obtain better efficiency, the two methods of PS activation were combined in a TCAP system, which resulted in complete TP degradation at $T=$ $60{ }^{\circ} \mathrm{C}$ and $[\mathrm{PS}]_{0}=\left[\mathrm{Fe}^{2+}\right]_{0}=2 \mathrm{mM}$. The reaction followed a pseudo-first order reaction rate, with $k_{\mathrm{obs}}=5.6( \pm 0.4) \times$ $10^{-2} \mathrm{~min}^{-1}$. The effects of $[\mathrm{PS}]_{0}:\left[\mathrm{Fe}^{2+}\right]_{0}$ ratio, $[\mathrm{PS}]_{0}$ and temperature were tested, where the $1: 1$ ratio gave optimum results, and the degradation rate increased with increasing $[\mathrm{PS}]_{0}$ and temperature. Salinity inhibited the degradation process, while nitrates slightly enhanced the process. The presence of HAs inhibited TP degradation. TP was dissolved in real water samples of spring, sea and waste water, which showed lower degradation rates in comparison with DI water medium. Real factory effluent containing TP was obtained and showed total degradation of $[\mathrm{TP}]_{0}=160 \mathrm{mg} \mathrm{L}^{-1}$ within 180 and $40 \mathrm{~min}$ for $[\mathrm{PS}]_{0}=\left[\mathrm{Fe}^{2+}\right]_{0}=25$ and $100 \mathrm{mM}$, respectively. The degradation cost was estimated to $56.8 \$ \mathrm{per} \mathrm{m}^{3}$, for electricity price rates in the US at $[\mathrm{PS}]_{0}=\left[\mathrm{Fe}^{2+}\right]_{0}=50 \mathrm{mM}$. A degradation mechanism involving in situ evolved reactive oxidative species, mainly sulfate and hydroxyl radicals, was also suggested based on LC/MS/MS HRAM analyses supported by frontier molecular orbital theory calculations.

\section{Conflicts of interest}

There are no conflicts to declare. 


\section{Acknowledgements}

This research was funded in part by the Lebanese National Council for Scientific Research (Award Number 103250), the $K$ Shair CRSL fund (Award Number 103599), and the University Research Board (Award Number 103603) of the American University of Beirut and USAID-Lebanon through The National Academy of Sciences under PEER project 5-18 (Award number 103262). The authors are thankful to Prof. Faraj Hasanayn for his kind assistance in obtaining the theoretical study data. Additionally, the authors are thankful to Eng. Joan Younes, senior technician Simon Al-Ghawi and the glass blower at the chemistry department, Boutros Sawaya, for their technical assistance and the personnel of the K. Shair CRSL for their kind help.

\section{References}

1 American Society of Health-System Pharmacists, Theophylline, https://medlineplus.gov/druginfo/meds/ a681006.html, 2017.

2 C. A. Shively and S. M. Tarka, Prog. Clin. Biol. Res., 1984, 158, 149-178.

3 K. Noguera-Oviedo and D. S. Aga, J. Hazard. Mater., 2016, 316, 242-251.

4 A. Wennmalm and S. C. Council, in Encyclopedia of Environmental Health, 2011, pp. 462-471.

5 A. Zenker, M. R. Cicero, F. Prestinaci, P. Bottoni and M. Carere, J. Environ. Manage., 2014, 378-387.

6 T. U. Berendonk, C. M. Manaia, C. Merlin, D. Fatta-Kassinos, E. Cytryn, F. Walsh, H. Bürgmann, H. Sørum, M. Norström, M. N. Pons, N. Kreuzinger, P. Huovinen, S. Stefani, T. Schwartz, V. Kisand, F. Baquero and J. L. Martinez, Nat. Rev. Microbiol., 2015, 310.

7 O. A. Jones, J. N. Lester and N. Voulvoulis, Trends Biotechnol., 2005, 163-167.

8 T. Heberer, Toxicol. Lett., 2002, 131, 5-17.

9 M. E. Rybak, M. R. Sternberg, C.-I. Pao, N. Ahluwalia and C. M. Pfeiffer, J. Nutr., 2015, 145, 766-774.

10 P. Rajasulochana and V. Preethy, Resour.-Effic. Technol., 2016, 2, 175-184.

11 Y. Luo, W. Guo, H. H. Ngo, L. D. Nghiem, F. I. Hai, J. Zhang, S. Liang and X. C. Wang, Sci. Total Environ., 2014, 473-474, 619-641.

12 Y. Yang, Y. S. Ok, K.-H. Kim, E. E. Kwon and Y. F. Tsang, Sci. Total Environ., 2017, 596-597, 303-320.

13 S. A. Snyder, Ozone: Sci. Eng., 2008, 30, 65-69.

14 J. Doummar, K. Nödler, T. Geyer and M. Sauter, Assessment and Analysis of Micropollutants 2010-2011.

15 S. Sun, J. Jiang, S. Pang, J. Ma, M. Xue, J. Li, Y. Liu and Y. Yuan, Sep. Purif. Technol., 2018, 201, 283-290.

16 R. Liang, S. Luo, F. Jing, L. Shen, N. Qin and L. Wu, Appl. Catal., B, 2015, 176-177, 240-248.

17 M. M. Sunil Paul, U. K. Aravind, G. Pramod, A. Saha and C. T. Aravindakumar, Org. Biomol. Chem., 2014, 12, 56115620.
18 I. Kim, N. Yamashita and H. Tanaka, Chemosphere, 2009, 77, 518-525.

19 R. Liang, A. Hu, W. Li and Y. N. Zhou, J. Nanopart. Res., 2013, 15, 1990.

20 N. S. Shah, A. D. Rizwan, J. A. Khan, M. Sayed, Z. U. H. Khan, B. Murtaza, J. Iqbal, S. U. Din, M. Imran, M. Nadeem, A. H. Al-Muhtaseb, N. Muhammad, H. M. Khan, M. Ghauri and G. Zaman, Process Saf. Environ. Prot., 2018, 117, 473-482.

21 F. Ali, J. A. Khan, N. S. Shah, M. Sayed and H. M. Khan, Process Saf. Environ. Prot., 2018, 307-314.

22 A. Ghauch, A. Baalbaki, M. Amasha, R. El Asmar, O. Tantawi, R. El Asmar and O. Tantawi, Chem. Eng. J., 2017, 317, 10121025.

23 M. Amasha, A. Baalbaki, S. Al Hakim, R. El Asmar and A. Ghauch, J. Adv. Oxid. Technol., 2018, 21, 261-273.

24 S. Naim and A. Ghauch, Chem. Eng. J., 2016, 288, 276-288.

25 A. Ghauch, G. Ayoub and S. Naim, Chem. Eng. J., 2013, 228, 1168-1181.

26 A. Ghauch, A. M. Tuqan and N. Kibbi, Chem. Eng. J., 2015, 279, 861-873.

27 A. Ghauch, A. M. Tuqan, N. Kibbi and S. Geryes, Chem. Eng. J., 2012, 213, 259-271.

28 A. Ghauch, A. M. Tuqan and N. Kibbi, Chem. Eng. J., 2012, 197, 483-492.

29 A. Ghauch and A. M. Tuqan, Chem. Eng. J., 2012, 183, 162171.

30 A. Fernandes, P. Makoś and G. Boczkaj, J. Cleaner Prod., 2018, 195, 374-384.

31 Y. Gao, N. Gao, Y. Deng, Y. Yang and Y. Ma, Chem. Eng. J., 2012, 195, 248-253.

32 L. Bu, S. Zhou, Z. Shi, L. Deng, G. Li, Q. Yi and N. Gao, Environ. Sci. Pollut. Res., 2016, 23, 2848-2855.

33 C. Tan, N. Gao, S. Zhou, Y. Xiao and Z. Zhuang, Chem. Eng. J., 2014, 253, 229-236.

34 M. Amasha, A. Baalbaki and A. Ghauch, Chem. Eng. J., 2018, 350, 395-410.

35 G. Mark, M. N. Schuchmann, H. P. Schuchmann and C. von Sonntag, J. Photochem. Photobiol., A, 1990, 55(2), 157-168.

36 S. Al Hakim, S. Jaber, N. Zein Eddine, A. Baalbaki and A. Ghauch, Chem. Eng. J., 2020, 380, 122478.

37 M. J. Frisch, G. W. Trucks, H. B. Schlegel, G. E. Scuseria, M. A. Robb, J. R. Cheeseman, G. Scalmani, V. Barone, B. Mennucci, G. A. Petersson, H. Nakatsuji, M. Caricato, X. Li, H. P. Hratchian, A. F. Izmaylov, J. Bloino, G. Zheng, J. L. Sonnenberg, M. Hada, M. Ehara, K. Toyota, R. Fukuda, J. Hasegawa, M. Ishida, T. Nakajima, Y. Honda, O. Kitao, H. Nakai, T. Vreven, J. A. Montgomery Jr, J. E. Peralta, F. Ogliaro, M. Bearpark, J. J. Heyd, E. Brothers, K. N. Kudin, V. N. Staroverov, R. Kobayashi, J. Normand, K. Raghavachari, A. Rendell, J. C. Burant, S. S. Iyengar, J. Tomasi, M. Cossi, N. Rega, J. M. Millam, M. Klene, J. E. Knox, J. B. Cross, V. Bakken, C. Adamo, J. Jaramillo, R. Gomperts, R. E. Stratmann, O. Yazyev, A. J. Austin, R. Cammi, C. Pomelli, J. W. Ochterski, R. L. Martin, K. Morokuma, V. G. Zakrzewski, G. A. Voth, P. Salvador, J. J. Dannenberg, S. Dapprich, A. D. Daniels, 
Ö. Farkas, J. B. Foresman, J. V Ortiz, J. Cioslowski and D. J. Fox, Gaussian, Inc., Wallingford CT, 2013.

38 C. Lee, W. Yang and R. G. Parr, Phys. Rev. B: Condens. Matter Mater. Phys., 1988, 37, 785-789.

39 A. D. Becke, Phys. Rev. A: At., Mol., Opt. Phys., 1988, 38, 30983100.

40 S. Y. Oh, H. W. Kim, J. M. Park, H. S. Park and C. Yoon, J. Hazard. Mater., 2009, 168, 346-351.

41 I. M. Kolthoff, A. I. Medalia and H. P. Raaen, J. Am. Chem. Soc., 1951, 73, 1733-1739.

42 L. W. Matzek and K. E. Carter, Chemosphere, 2016, 151, 178188.

43 W. Shang, Z. Dong, M. Li, X. Song, M. Zhang, C. Jiang and S. Feiyun, Chem. Eng. J., 2019, 361, 1333-1344.

44 I. Hussain, Y. Zhang and S. Huang, RSC Adv., 2014, 4(7), 3502-3511.

45 D. Wu, X. Li, J. Zhang, W. Chen, P. Lu, Y. Tang and L. Li, Sep. Purif. Technol., 2018, 207, 255-261.

46 M. Nie, C. Yan, X. Xiong, X. Wen, X. Yang, Z. lv and W. Dong, Chem. Eng. J., 2018, 348, 455-463.

47 H. A. Gorrell, Am. Assoc. Pet. Geol. Bull., 1958, 42, 2513.

48 Environment Protection Authority (EPA), in South Australia, Salinity, http://www.epa.sa.gov.au/environmental_info/ water_quality/threats/salinity, accessed 15 June 2017.

49 D. A. Armstronga, R. E. Huie, S. Lymar, W. H. Koppenol, G. Merényi, P. Neta, D. M. Stanbury, S. Steenken and P. Wardman, BioInorg. React. Mech., 2013, 9(1-4), 59-61.

50 C. Liang, Z.-S. Wang and N. Mohanty, Sci. Total Environ., 2006, 370, 271-277.

51 K. Hasegawa and P. Neta, J. Phys. Chem., 1978, 82, 854-857.

52 Y. Fan, Y. Ji, D. Kong, J. Lu and Q. Zhou, J. Hazard. Mater., 2015, 300, 39-47.

53 S. Norzaee, M. Taghavi, B. Djahed and F. K. Mostafapour, J. Environ. Manage., 2018, 215, 316-323.

54 S. Wang, J. Wu, X. Lu, W. Xu, Q. Gong, J. Ding, B. Dan and P. Xie, Chem. Eng. J., 2019, 358, 1091-1100.
55 D. Keeney and R. A. Olson, Crit. Rev. Environ. Control, 1986, 16, 257-304.

56 S. J. Boggs, D. Livermore and M. G. Seitz, Humic substances in natural waters and their complexation with trace metals and radionuclides: a review, 129 references, 1985.

57 L. Liu, S. Lin, W. Zhang, U. Farooq, G. Shen and S. Hu, Chem. Eng. J., 2018, 346, 515-524.

58 M. D. Paciolla, S. Kolla and S. A. Jansen, Adv. Environ. Res., 2002, 7(1), 169-178.

59 J. R. Bolton, K. G. Bircher, W. Tumas and C. A. Tolman, Pure Appl. Chem., 2001, 73(4), 627-637.

60 F. Fardoun, O. Ibrahim, R. Younes and H. Louahlia-Gualous, Energy Procedia, 2012, 19, 310-320.

61 XE Currency Converter: LBP to USD, https://www.xe.com/ currencyconverter/convert/? Amount $=225 \&$ From $=$ LBP $\&$ To $=$ USD,.

62 J. A. V. Butler, C. N. Ramchandani and D. W. Thomson, J. Chem. Soc., 1935, 280-285.

63 Q. Wang, X. Lu, Y. Cao, J. Ma, J. Jiang, X. Bai and T. Hu, Chem. Eng. J., 2017, 328, 236-245.

64 K. Fukui, T. Yonezawa and H. Shingu, J. Chem. Phys., 1952, 20(4), 722-725.

65 H. Yang, S. Zhou, H. Liu, W. Yan, L. Yang and B. Yi, J. Environ. Sci., 2013, 25(8), 1680-1686.

66 D. Miao, J. Peng, X. Zhou, L. Qian, M. Wang, L. Zhai and S. Gao, Chemosphere, 2018, 207, 174-182.

67 H. Liu, P. Sun, M. Feng, H. Liu, S. Yang, L. Wang and Z. Wang, Appl. Catal., B, 2016, 187, 1-10.

68 E. Lipczynska-Kochany, G. Sprah and S. Harms, Chemosphere, 1995, 30, 9-20.

69 J. M. Monteagudo, A. Durán, J. Latorre and A. J. Expósito, J. Hazard. Mater., 2016, 306, 77-86.

70 X. Xu, G. Pliego, J. A. Zazo, J. A. Casas and J. J. Rodriguez, J. Hazard. Mater., 2016, 318, 355-362. 